\title{
ASSESSMENT OF SENTINEL-2-DERIVED VEGETATION INDICES FOR THE ESTIMATION OF ABOVE-GROUND BIOMASS/CARBON STOCK, TEMPORAL DEFORESTATION AND CARBON EMISSIONS ESTIMATION IN THE MOIST TEMPERATE FORESTS OF PAKISTAN
}

\author{
KHAN, K. $.^{*}-$ IQBAL, J. ${ }^{1}-$ ALI, A. ${ }^{2}-$ KHAN, S. N. ${ }^{1}$ \\ (phone: +92-51-9085-4473) \\ ${ }^{2}$ Pakistan Forest Institute, Peshawar, Pakistan \\ (phone: +92-91-9221-226) \\ *Corresponding author \\ e-mail: kkhan.ms16igis@igis.nust.edu.pk
}

${ }^{1}$ Institute of Geographical Information Systems, School of Civil and Environmental Engineering, National University of Sciences and Technology (NUST), Islamabad, Pakistan

(Received $3^{\text {rd }}$ Jul 2019; accepted $14^{\text {th }}$ Nov 2019)

\begin{abstract}
In developing countries like Pakistan, leading $\mathrm{CO}_{2}$ emission source is deforestation of temperate forests, which must be estimated precisely for resilient climate policy. This research evaluates temporal deforestation, above and below ground carbon stock, biomass estimation potential of vegetation indices derived from Sentinel-2 imagery, carbon emission from deforestation and carbon sequestration potential. Forest inventory data was collected and used in allometric equations, to calculate aboveground biomass and carbon stock. The temporal deforestation rate was estimated using LANDSAT 7 \& 8 (20002015) data. Biomass was predicted using the most optimal VI by developing linear regression model. The carbon emission from deforestation was estimated using activity data and emission factor. Above ground biomass and carbon stock estimated for the study area were $148.79 \mathrm{t} / \mathrm{ha}$ and $69.93 \mathrm{t} / \mathrm{ha}$ with mean $\mathrm{CO}_{2}$ equivalent value of $322.5 \mathrm{t} / \mathrm{ha}$. The estimated forest cover change using Landsat satellite data (2000-2015) was about $16.88 \%$ with $2.51 \%$ annual deforestation rate. Relationship between red-edge VIs and AGB were the best and reduced saturation problem. Carbon loss in fifteen years were about $6.96 \mathrm{Mt} \mathrm{CO}_{2} \mathrm{e}$. The carbon sequestration capacity for the study area was $82.07 \mathrm{t} / \mathrm{ha} \pm 13 \mathrm{t} / \mathrm{ha}$. This research methodology is cost effective, helps in sustainable forest management and reduces carbon losses.
\end{abstract}

Keywords: activity data, carbon losses, climate change, GIS, REDD+, remote sensing, sequestration potential

\section{Introduction}

In sequestration of carbon forests play a significant role and act as a natural carbon sink to mitigate climate change. There is about $33 \%$ area of the world covered with forests which accounts for $80 \%$ aggregate over ground earthbound carbon and $40 \%$ below canopy carbon (Noble et al., 2000). The rate of carbon storage in the world's forests is estimated to be about $4.1 \mathrm{GtCyr}^{-1}$ from 2000 to 2007 (Stinson et al., 2011). The significant contribution of greenhouse gas emission is due to forest fire, degradation, fossil fuel burning, and deforestation. The Greenhouse gas emission can be reduced through sustainable management, conservation, restoring forest and increment in forest trees (Noble et al., 2000). While conservation of forest not only act to be the source of carbon but also gives a more extensive scope of services and products to people, and it also has natural, financial, social, ecological and environmental benefits. The carbon density in the forest is higher than in other type of environments and hence has a role in 
decreasing atmospheric carbon emissions (Stinson et al., 2011). According to IPCC, outflow of carbon dioxide from a change in land use is about $10 \%$ of the outflows that are from human-made activities. As deforestation, degradation and erosion occur it leads to an increase in carbon emission and a decrease in sequestration (Dube et al., 2012). About $50.8 \%$ of coniferous wood comprises of carbon and herbs, woody plants in forest act as essential storage of carbon (Thomas and Martin, 2012). There is a significant role of forest in global climate change as about $17.4 \%$ of yearly $\mathrm{CO}_{2}$ discharge are due to degradation and deforestation of forests (Egenhofer, 2007). Forests located at highlatitude in the northern hemisphere act as major sinks of carbon and play a leading part in reducing emissions of carbon in the global carbon cycle (Schimel et al., 2000; Valentini et al., 2000). Therefore, countries having more risk of deforestation and degradation should increase the protected areas as an effort for the conservation of their forest environmental services (Jackson and Baker, 2010; Lippke et al., 2003). Of the 3984 million ha worldwide forest area it is estimated that about $13.25 \%$ of the areas are protected forests (Keenan et al., 2015).

According to IPCC, a baseline must be created for the assessment of carbon stock, and it needs a mapping of vegetation biomass arrangement from local to worldwide scale (Dobbs et al., 2014; Pan et al., 2011). To counterbalance carbon release at less expense and obtain sustainable forest management REDD+ has promoted interest at international level (Caparros et al., 2011; Neilson et al., 2006). The primary aim of REDD+ is to make motivators for decreasing discharges from degradation and deforestation and enhancement of carbon stock through improvement, sustainable forest management and conservation in the developing countries (Balderas Torres and Skutsch, 2012). According to the strategy of UNFCCC on REDD+ release of carbon from the forests will be ascertained and the compensation will be given to developing countries in favor of a decrease in carbon emission. In order to receive the compensation, they should indicate that in the forest they increased carbon storage rate and due to degradation and deforestation national carbon release rate are decreased (increasing carbon sequestration) (Le Toan et al., 2011; Sessa and Dolman, 2008). Then an arrangement of "national forest reference emission level/reference levels (REL/RL) (or sub-national REL/RLs as an interval measure) and safeguards" should be set up and then by those results financing should be given (Brown, 2002; Lu, 2006).

Pakistan has a forest cover of 4.55 million hectares (5.1\%). Most of the forest in the country is located in the northern part which is generally natural and coniferous. These forests can be categorized as moist temperate, dry temperate, sub-tropical chir pine and sub-alpine forests. These types comprise about $54 \%$ of the area of forests. Forest/tree cover stretches out over a region of 1.51 million ha (except alpine pasture), which makes about $20.3 \%$ of total land area of Khyber Pakhtunkhwa province. In Khyber Pakhtunkhwa, the natural forests comprise of sub-tropical chir pine forests having Pinus roxberghii (Chir pine), and Quercus spp. The dry and moist temperate forests have dominant species of Pinus wallichiana (Blue pine), Picea smithiana (Spruce) and Cedrus deodara (Deodar) as well as several broad-leaved species such as Acer caesium (Maple), Aesculus indica (Horse chestnut), Juglans regia (Walnut) and Prunus padus (Bird cherry).

It is estimated that over 1 million hectares of forests are lost in Pakistan between 1990 and 2015 (FAO, 2014), which is about $25 \%$ of its natural forests with the average deforestation rate of 42,200 ha per year. The above ground and below ground biomass are reduced due to deforestation at an annual rate of $2.2 \%$, totaling over 100 million tons $\mathrm{CO}_{2}$ 
e; from 330 million tons of $\mathrm{CO}_{2}$ in 1990 to 213 million tons of $\mathrm{CO}_{2}$ in 2010 (WorldBank, 2015). Deforestation is mainly driven by increasing demand of forest product such as fuelwood, fodder, and timber, outstripping the supply of these products, population expansion, grazing, land use change and illegal harvesting (FCPF, 2013). Coniferous forest area has been rapidly declining due to the high value of conifer timber. Government forests have been transferred to the non-forestry and commercial purpose such as infrastructure development, agriculture, defense, and tourism in recent decades (WorldBank, 2015). In Pakistan coniferous forests are considered to be the most important species for preservation due to their high carbon stock, the presence of peatlands, and longer maturity age (Karki et al., 2014). Deforestation and land-use change are identified as major sources of emissions. Forestry and land use change contribute approximately 3\% to Pakistan's total GHG emissions (around $9 \mathrm{MtCO}_{2} \mathrm{e}$ in 2008) (Aslam et al., 2011). Net emissions are forecast to rise from 10,000 $\mathrm{GgCO}_{2}$ e in 2011 to 13,000 $\mathrm{GgCO}_{2}$ in 2020 and 15,000 $\mathrm{GgCO}_{2}$ e in 2030 (PAEC-ASAD: Athar, 2009).

Pakistan commenced REDD+ activities in 2010 and it is a UN-REDD partner country. In 2012 REDD+ Preparedness Phase (R-PP) for Pakistan was initiated by the Worldwide Fund for Nature Pakistan (WWF-Pakistan), the International Center for Integrated Mountain Development (ICIMOD), and the Climate Change Ministry. For REDD+ guidance has been recommended by the United Nation Framework Convention on Climate Change using RS and ground-based carbon measurement for carbon, biomass estimation, GHG emissions and change in forest area due to deforestation and degradation. Subsequently, there is an absence of data for the appraisals of reasonable REDD+ action regions. Furthermore, tools have been developed since the 1990s to identify which zones are the most vulnerable to deforestation and ultimately releasing carbon (Päivinen et al., 2001; Piao et al., 2005). However, less data availability can be a barrier in their use in developing countries (Angelsen, 2009; Sitoe et al., 2014). The decrease in carbon emission must be surveyed in order to create installments for REDD+ activity at the national or sub-national level. This incorporates the evaluation of the two factors, i.e., activity data (a change which occurred in a particular period in a forest area) and emission factor (change occurred in carbon stock of forest). Both of these factors must be assessed through the nations taking part in REDD+ through the usage of authentic MRV systems (Plugge et al., 2013). Field data and RS gives us a proficient answer to observe the condition and changes of forest carbon stock (Melville et al., 2015; Tomppo et al., 2008).

The conventional field inventory methods of forest carbon stock inventory are considered more accurate. The field technique can be further divided into two methods, i.e., destructive and non-destructive methods. The destructive method is also called harvest method (Gibbs et al., 2007). In this method the trees in a study area are all felled in the destructive method then their parts like a tree trunk, leaves, and branches are weighed and then after oven drying the weight of these components are recorded again. When biomass estimation is done without tree felling then it is called the non-destructive method, and it can be used for threatened and protected species (Montes et al., 2000), the above-ground biomass can also be evaluated from volume tables using DBH (Diameter at breast height) and trees height as a reference variable. These two parameters, i.e., height and DBH can be easily obtained and then using the allometric model tree biomass can be determined (Picard et al., 2012). However, it presents various challenges including limited to small scale survey, expensive, and time-consuming methods. 
To estimate above ground biomass studies have been conducted using optical satellite images of medium-resolution (Fernández-Manso et al., 2014; Gizachew et al., 2016; Lu et al., 2002; Muukkonen and Heiskanen, 2005). For estimation of biomass VIs were derived in these studies from optical images (Landsat, ASTER) because there is correlation between AGB assessed from field data and VIs. Major problems in estimation of above ground biomass is low spatial resolution and saturation problem in the satellite imageries (Lu, 2005). Sentinel-2 satellite which is recently launched have high spatial, spectral and temporal resolution and also have new red-edge spectral band for vegetation monitoring which will further increase the accuracy of AGB estimation (Delegido et al., 2011).

Two components restrict carbon sequestration potential, i.e., carbon cannot be retained by the forests forever, and as growth occurs in the forest, a saturated state will be attained which is called as the carbon carrying capacity (CCC) (Keith et al., 2009). It means that carbon sequestration of forests has a maximum point of confinement (Odum) known as carbon sequestration potential (CSP) (Keith et al., 2009). On the other hand, degradation and deforestation conservation of all the forests is not possible. Hence for reciprocation between fulfilling forest products demands of humans and saving carbon sink capacity of forests attention should be given to those forests having high Carbon Carrying Capacity (CCC) and Carbon Sequestration Potential (CSP). Carbon density is decided by two variables which are the age of the forest (Pregitzer and Euskirchen, 2004) and climate (precipitation, temperature, etc.). Forests having old growth contain higher biomass and can represent the carbon carrying capacity of biomes (Keith et al., 2009). Assessment of Carbon Sequestration Potential (CSP) is challenging as old-growth forest data is not available (Cramer et al., 2001).

Geographic information systems (GIS) and Remote sensing (RS) techniques can effectively evaluate and analyze forest carbon stock at a regional and global scale. However, RS cannot directly measure carbon stock and need ground-based traditional field survey techniques. The RS techniques have been reported to be more accurate and useful where forest carbon densities are low, i.e., in temperate forest condition and young stand. However, the RS techniques are not very accurate in the tropical forest which are the most carbon-rich due to saturation of the remote sensing signals (Rosenqvist et al., 2003). Furthermore, since most of the remote sensing sensors are optical (visible and near-infrared bands) in nature; therefore, their use is limited due to higher cloud cover. To overcome this issue active remote sensing techniques like LIDAR are now becoming a prominent approach (Asner, 2001).

Currently, Very High-Resolution Satellite (VHRS) optical imagery, i.e., Quick bird, Geo-eye, are being used for the extraction of forest inventory parameters (Baral, 2011). Phua et al. (2014) found a strong positive correlation between forest inventory data such as DBH and Height and Satellite-based crown area data. SPOT, Landsat and ASTER imagery have been used for the estimation of AGB through the extraction of Vegetation Indices (VIs) from imagery and then through statistical techniques their relationship assessment with AGB. According to Silleos et al. (2006), optical satellite imagery sunview angle, atmospheric effects, and soil-back ground can be reduced by VIs. Few studies (Fernández-Manso et al., 2014; Gizachew et al., 2016; Lu et al., 2002; Muukkonen and Heiskanen, 2005) reported on relationship between forest biomass and VIs derived from Sentinal-2 imagery. Hence, more research is needed on abilities of VIs which are obtained from optical satellite images of medium-resolution for forest biomass evaluation, specifically in Sentinel-2 satellite image which is recently launched. 
Most of the studies discussed have assessed forest biomass/carbon stock using remote sensing techniques. This study estimates above and below ground carbon stock, temporal deforestation, potential of several type of vegetation indices from sentinel-2 imagery in estimation of biomass, carbon emission from deforestation and carbon sequestration potential using forest inventory and remote sensing data for sustainable management of forests.

Major objectives of the study were:

- Generating land cover maps for the assessment of temporal deforestation.

- Estimating above and below ground biomass/carbon stock from forest inventory data.

- Potential of Several type of vegetation indices from sentinel-2 imagery in the estimation of biomass.

- Producing and validating biomass maps by developing regression model between forest inventory and remotely sensed data.

- Quantifying carbon losses from land use change using forest inventory and remote sensing data.

- To assess the carbon sequestration potential of study area.

\section{Materials and methods}

\section{Study area}

Battagram (latitude $34.41 \mathrm{~N}$ and longitude 73.1 E), a district of Khyber-Pakhtunkhwa (KP) province of Pakistan was selected as a study area (Fig. 1). Its total area is about $1507 \mathrm{~km}^{2}$. The district terrain is mountainous in nature with an altitude above $4000 \mathrm{~m}$ covered with thick forest. There are four ranges in Battagram district namely Hillan, Battagram, Allai, and Pashto range. It includes forests, rangeland, alpine pasture, and agriculture. The average temperature of the district is $18.5^{\circ} \mathrm{C}$ with an average annual precipitation of $1218 \mathrm{~mm}$ during winter, snowfall used to be heavy on the northern part at higher altitudes of the mountainous regions.

The Battagram forests can be characterized as Himalayan moist temperate forest and Sub-alpine temperate regions. The legal status of most of the forest found is Guzara forest (community-owned forests).

The underlying rock in the area consists of gneissose - schist, gneiss, granitoid-schist and mica-schist. Shales occur in chir zone. Metamorphic and plutonic igneous rocks are also found. Low grade metamorphic rocks like (i) Graphite Schist, (ii) Recrys-talline limestone, (iii) Amphibole Schist (iv) Quart-mica Schist (v) Green Schist are exposed in the southern and the south-western part of the area.

\section{Methods}

Sample plots were laid out using stratified cluster sampling technique in the study area for the collection of forest inventory data. The forest inventory data was collected in June 2016 on tree diameter and height parameters and used in the allometric equations for the estimation of biomass. About 11 different vegetation indices (VIs) were derived from Sentinel-2 imagery to establish a relationship between VIs, and above ground biomass (AGB). For linear regression model development best VI was used in order to predict biomass. To assess the land use/landcover satellites Landsat-7 and Landsat- 8 imagery data were used. Carbon emissions were estimated by 
multiplying the emission factor with activity data. Activity data and emission factor were calculated from remotely sensed images and forest inventory data respectively. Finally, carbon sequestration potential was assessed from carbon carrying capacity (CCC) and carbon density. The complete methodology flow chart is given in Figure 2.

\section{Data collection/field procedure}

A total of fifty-five (55) plots were sampled using a stratified cluster sampling technique in the study area. Circular plots of radius $17.84 \mathrm{~m}$ were taken with a plot to plot distance of $200 \mathrm{~m}$. Before final data processing field measurements errors were corrected (McRoberts et al., 2010) as accuracy and results of inventory is affected by these errors (Molto et al., 2013). Sample plots shape and size were taken according to UNFCCC guidelines. For carbon inventory trees having $\mathrm{DBH} \geq 5 \mathrm{~cm}$ were measured (Nizami, 2012). Plot measurement includes information about GPS coordinates, aspect, elevation, forest type, species, diameter at breast height $(\mathrm{DBH})$, crown cover and tree height. The DBH was measured at 1.3 meters above the ground from collar point of trees on the uphill side and according to field measurement standard while tree height was measured by Haga Altimeter. The plot to plot navigation was done by Sunnto Compass, and within plot distance and plot to plot, the distance was measured using measuring tape (Nizami, 2012). Defected trees such as a buttressed tree, forked trees, and trees having butt log damaged by fire were also measured. All the field data was recorded in departmental field inventory forms and further transferred to Microsoft Excel sheets for the calculation of biomass and carbon stocks.

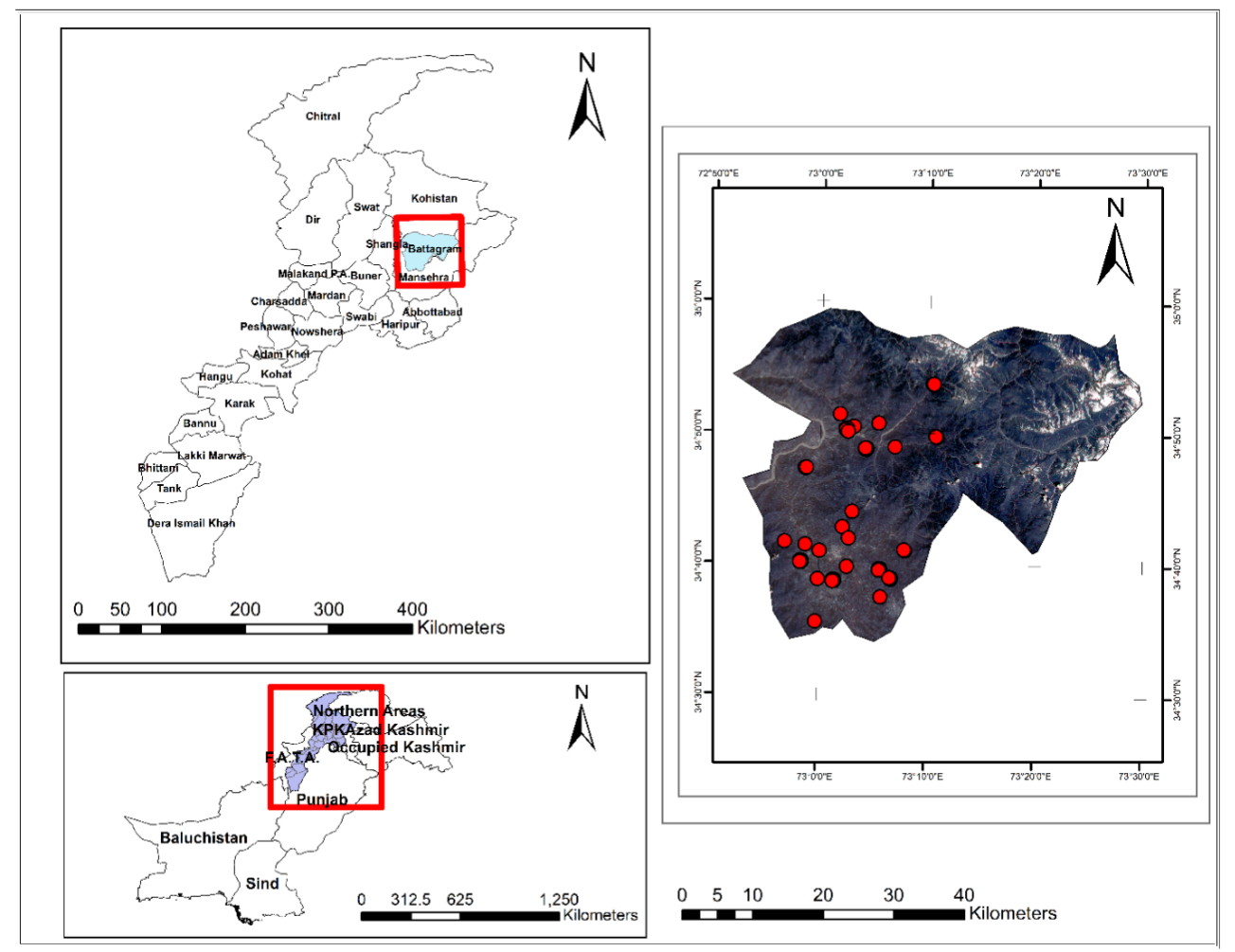

Figure 1. Study area map is showing its location, sentinel-2 imagery of study area and forest inventory sample plots analyzed in the study area using stratified cluster sampling according to national forest inventory and field surveying manual and UNFCCC guidelines with a plot to plot distance of $200 \mathrm{~m}$ 


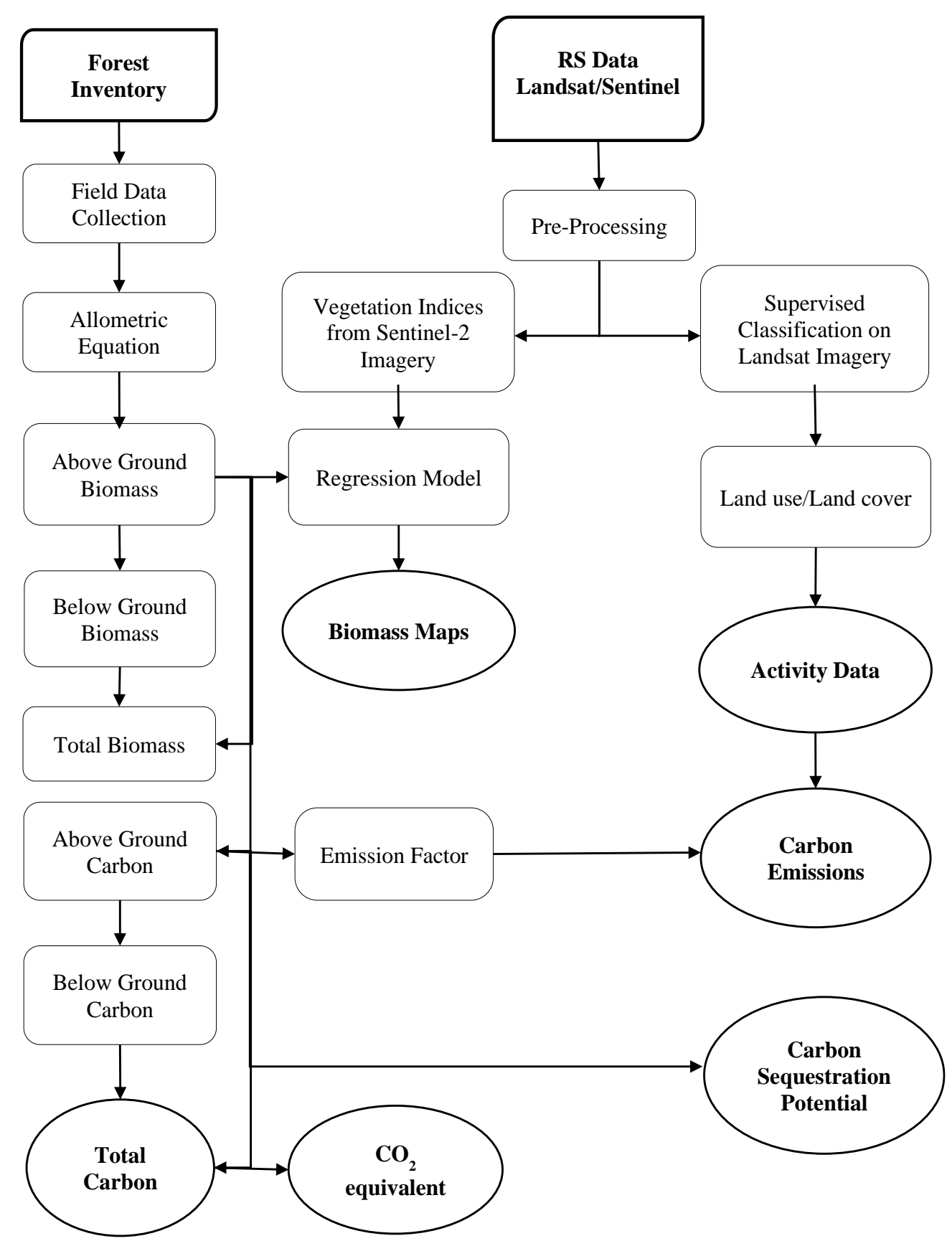

Figure 2. Workflow of the research method and data types used

\section{Calculation of above/below ground biomass and carbon stock}

The AGB can be computed by two methods: (i) Biomass expansion method and (ii) use of Allometric equations. In Biomass expansion factor method first volume is calculated with field measurements such as height, DBH, and Form factors and then the volume is multiplied with wood density and BEF (Biomass Expansion Factor) in order to get final biomass (Nizami, 2012). It is multiplied with wood density because there is a relationship between biomass and density of wood, i.e. the higher the density, the higher the biomass. While it is multiplied with BEF because we have calculated the volume of stem only while the biomass is also stored in branches so we cannot measure 
the volume of each branch of tree, therefore, we multiply it with a fixed value of BEF for each species. For calculation of AGB allometric equations were used by using forest stands parameters such as trees height and Diameter at breast height (DBH). Allometric equations are the regression equations between forest attributes used for the estimation of tree height, biomass or other growth attributes (Chave et al., 2005; Gao et al., 2016; Shi and Liu, 2017). Hence with the use of field measurements such as diameter and height, we can assess biomass (Gao et al., 2015). The height represents primary growth while the secondary growth is represented by the diameter of trees. The allometric equations (Table Al in the Appendix) which were used in this research were formulated by Ali (Ali, 2015). These allometric equations are different for different species; it means that these are species specific. These allometric equations are acceptable for all bioclimatic conditions and forest types. The above ground biomass (AGB) in kgs per plot was then converted into per hectare by multiplying AGB of the plot with 10 as the size of our plot was one-tenth of a hectare. Then divided with 1000 in order to obtain AGB in tons. Finally, in order to obtain AGC (Above Ground Carbon stock), the biomass in tons was multiplied with 0.47 , a conversion factor formulated by IPCC (Eq. 1; IPCC, 2006). According to the conversion factor, about one half of total dry biomass is carbon stock for given species. For assessment of BGB (below ground biomass) and BGC (below ground carbon stocks) the AGB (above ground biomass) and AGC (above ground carbon) were multiplied with a conversion factor of 0.26 (Ali et al., 2018; IPCC, 2006; Ravindranath and Ostwald, 2008). For the estimation of total carbon stocks above ground carbon and below ground carbon were added and converted into $\mathrm{CO}_{2}$ equivalent by multiplying total carbon stocks with a 3.66 factor. While 3.66 is a ratio of molecular mass to the atomic mass of carbon.

\section{$\mathrm{C}=\mathrm{AGB} \times \mathrm{CF}$}

where $\mathrm{C}$ is Carbon stock, $\mathrm{AGB}$ is above ground biomass and $\mathrm{CF}$ is Conversion factor (0.47).

\section{Satellite data}

To generate biomass map the cloud-free $(\leq 10 \%)$ Sentinel-2 image data (orthorectified imagery with projection system of UTM/WGS84), of July 2016 was downloaded (http://www.earthexplorer.usgs.gov). Because of high spatial resolution (10 m) of imagery as compare to other open source satellite products it was considered acceptable for research. The Spectral resolution of Sentinel-2 imagery is high with Red, Blue, Green, and NIR bands; hence it is considered suitable for vegetation studies. For monitoring vegetation, it additionally accompanies three red-edge spectral bands.

Using ENVI software Sentinel-2 optical imagery was preprocessed for radiometric correction in order to improve image quality. The radiometric correction primary purpose was to reduce sun angle and atmospheric effects (Baillarin et al., 2012). In QGIS software semi-automatic classification plugin was used for the transformation of imagery from radiance to surface reflectance through the application of Dark Object Subtraction (DOS). The DOS method works by removing in every band the darkest pixel which will be affected by scattering in the atmosphere (Chavez Jr, 1988). This method does not need ground truth data as it is image based and is easy to apply (Chavez, 1996). The shortwave infrared band and red-edge band with a spatial resolution of $20 \mathrm{~m}$ were resampled into a $10 \mathrm{~m}$ spatial resolution using resampling tool in ArcMap. 
Computation of VIs was done through various spectral bands combination having $10 \mathrm{~m}$ and $20 \mathrm{~m}$ spatial resolution hence to make all bands of same spatial resolution $(10 \mathrm{~m})$ resampling was performed. The imagery was clipped using the study area shapefile.

\section{Deriving vegetation indices}

Several vegetation indices have been reported in the literature for the derivation of biomass. In this study, three categories of vegetation indices were considered for the derivation of biomass, which includes: Broadband VIs, Canopy Water Content Indices, and Narrow Red Edge band VIs (Table A2). In broadband category, the sensitivity of vegetation indices is very high to canopy leaf area. The vegetation indices in the broadband category are sensitive to the canopy leaf area.

The Canopy Water Content Indices use the near-infrared spectral band and shortwave infrared (SWIR) spectral band. To study water content in the vegetation it is used. Through this VIs health of vegetation can be assessed as healthier vegetation have more carbon storage capacity as compared to trees having water stress. The Narrow Red Edge band vegetation indices use the near infra band. However, it does not utilize the red band rather it uses red-edge spectral band $(690-740 \mathrm{~nm})$. To study biophysical characters of vegetation these are mainly used (Mutanga and Skidmore, 2004b). These VIs show the vegetation photosynthesis in more detail than broadband indices. It overcomes the signal saturation issue of broadband indices which is due to high canopy density.

In this study twenty-five (25) different vegetation indices selected from the three broad categories were derived from high spectral and spatial resolution Sentinel-2 image of July 2016. Out of twenty-five indices, only eleven (11) vegetation indices were selected on the basis of their performance, i.e. having significant R-square value between the forty-five (45) field surveyed plots biomass and derived vegetation indices. However, only one vegetation index was selected on the basis of lowest root mean square error (RMSE) with the lowest p-value and high significant R-square value. A linear regression model was developed between the selected vegetation index and field surveyed biomass of the forty-five plots. The linear regression model was used in the ArcGIS software raster calculator to generate biomass map for the entire study area.

\section{Validation of biomass map}

The biomass map was validated using the remaining ten (10) plot data. Since out of fifty-five plot data only forty-five plots data were used to generate the linear regression model the rest of ten plot data was kept for validation of the biomass map. The biomass values were extracted from the thematic biomass maps for the 10 sites and compared with the field surveyed generated biomass data using the correlation coefficient, P-value and RMSE statistics. Model accuracy was assessed by the following formula (Eq. 2):

$$
\operatorname{RMSE}=\sqrt{\frac{\sum_{i=1}^{n}\left(y_{1}-\hat{y}\right)^{2}}{n}}
$$

where "Y $Y_{i}$ " is Measured value of biomass, " $\hat{Y}$ " is Estimated value of biomass and " $n$ " is Number of samples. 


\section{Activity data}

Activity data (forest change/deforestation) was assessed in the study area from the year 2000 to 2015 using the Landsat-7 and Landsat-8 satellite Data (http://www.earthexplorer.usgs.gov). The temporal satellite data was preprocessed in ERDAS IMAGINE software and supervised classification algorithm was applied for the assessment of land cover classes and to find the change in forest cover which had occurred in the last fifteen years. A thematic map was obtained of seven major land use classes, i.e. forest, glacier and snow, water, barren land, settlement, shrub and grassland, and agriculture. The forest in the study area was extracted, and forest change thematic map was derived by subtracting forest area of the thematic map of 2015 from the forest area of the thematic map of 2000 and finally the deforested areas were obtained. Equation 3 (Sader and Joyce, 1988) was used to assess the average annual deforestation rate in the study area.

$$
\text { Annual Rate }(\% \text { per year })=\left(\frac{\left(\left(\mathrm{Y}_{1}-\mathrm{Y}_{2}\right) \times 100\right)}{\left(\mathrm{Y}_{1} \times \mathrm{N}\right)}\right)
$$

where "Y ${ }_{1}$ " is the total area of forest on the initial date, i.e. 2000, "Y ${ }_{2}$ " is the total area of the forest on the final date, i.e. 2015 and " $\mathrm{N}$ " is the number of years in a particular period, i.e. 15 years.

\section{Carbon emission estimation}

To estimate carbon emission the activity data and emission factor were multiplied (Eq. 4; Plugge et al., 2013).

$$
\mathrm{CE}=\mathrm{AD} \times \mathrm{EF}
$$

where "CE" is Carbon Emissions, "AD" is Activity Data (Change in forest cover) and "EF" is Emission Factor which can be calculated using Equation 5 (REDD+, 2006).

$$
\mathrm{EF}=[(\mathrm{AGC} 2000-\mathrm{AGC} 2015) \times 3.66]
$$

where "EF" is Emission Factor, "AGC2000" is Above ground carbon for the year 2000, and "AGC2015". The Above ground carbon for the year 2015 while "3.66" or "44/12" is a conversion factor. This conversion factor is the ratio of molecular mass to the atomic mass of carbon.

\section{Carbon sequestration potential}

The storage capacity of carbon increases rapidly as the forest is in the developmental stage and hence forest act as a carbon sink. While the old forest (80-100 years age) carbon stock increases very slowly and exchange of carbon among the atmosphere and the forests reaches to a balanced state therefore forests reach to a stage of carbon neutrality (Zhou et al., 2002) and this old-growth forest could be taken as Carbon Carrying Capacity (CCC) reference of those forests having climatic condition similar to these old-growth forests. Assessment of Carbon Sequestration Potential (CSP) is challenging as old-growth forest data is not available (Cramer et al., 2001). 
Carbon Sequestration Potential of a particular forest type can be evaluated through the difference between carbon density of the current forest and old-growth forest as shown in Equation 6 (Hudiburg et al., 2009; Liu et al., 2011; Smithwick et al., 2002).

\section{$\mathrm{CSP}=\mathrm{CCC}-\mathrm{CD}$}

where CSP is Carbon Sequestration Potential, CCC is Carbon Carrying Capacity, and $\mathrm{CD}$ is Carbon Density.

\section{Results}

\section{Landuse landcover change detection}

The Landsat temporal (year 2000 and 2015) satellite data was classified into seven major classes (Glacier and snow, Water, Barren land, Settlement, Shrub and Grassland, Agriculture and Forest) (Fig. 3). Landsat-7 (ETM+) and Landsat-8 (OLI) data were used for generating LULC maps for the year 2000 and 2015. Over the fifteen years even though there was no significant change was found in the settlement $(0.3 \%)$, but a major decreasing change was observed in the forest $(-16.9 \%)$ and barren land $(-7.7 \%)$ while an increasing change was recorded in the agriculture $(12.2 \%)$. The data suggest that, since there was no significant change was found in the settlement most of the forest land was used for agricultural purposes while the major cause of deforestation could be illegal logging.

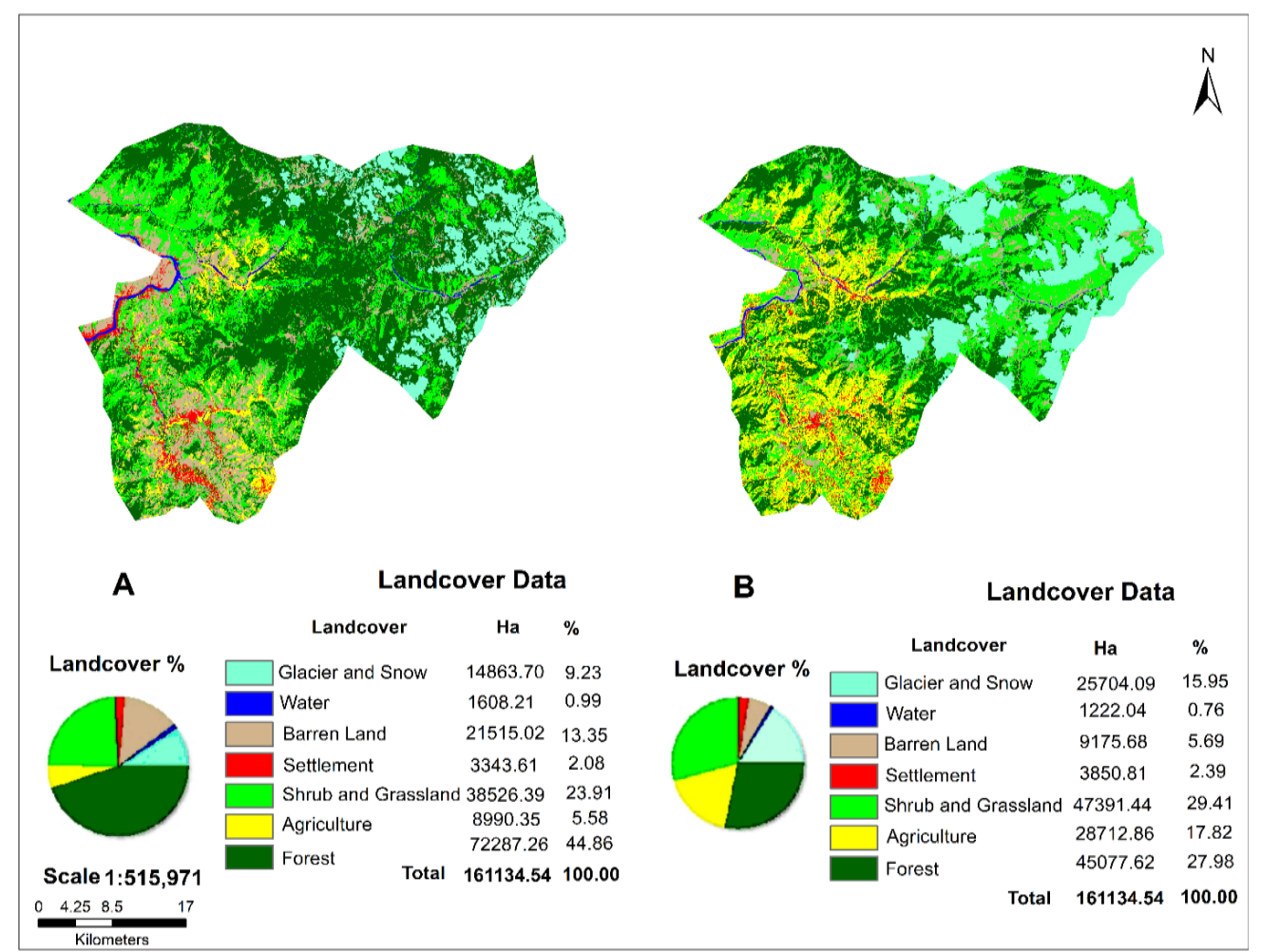

Figure 3. Study area Land cover/use map for the year 2000 (A) derived from Landsat-7 $($ ETM+) and Study area Land cover/use map for the year 2015 (B) derived from Landsat-8 (OLI/TIRS) using supervised classification and maximum likelihood algorithm in ERDAS Imagine 2015 
Figure 4 shows the extracted forest land cover area from the land cover/land use map. In 2000 forest area was 72287.26 ha $(44.86 \%$ of the total study area), which decreased to 45077.62 ha $(27.98 \%$ of the study area) in 2015 . It indicates a 27209.64 ha $(-16.88 \%)$ loss with an annual deforestation rate of $2.51 \%$, i.e. 1814.41 ha deforestation per year which is quite alarming. In order to decrease carbon emissions, forest conservation and sustainable forest management practices are required as the deforestation rate is very high in the study area. For agricultural purpose, natural forests are cleared hence disturbing the ecology of the area. Factors like illegal logging, wood harvesting for construction and fuel wood are the major reasons for deforestation. Moreover, the legal status of the forests in our study area is guzara forest which means it has community rights and all acts in guzara forests are allowed until and unless prohibited by the government, therefore, it is not protected or conserved like reserved forests.

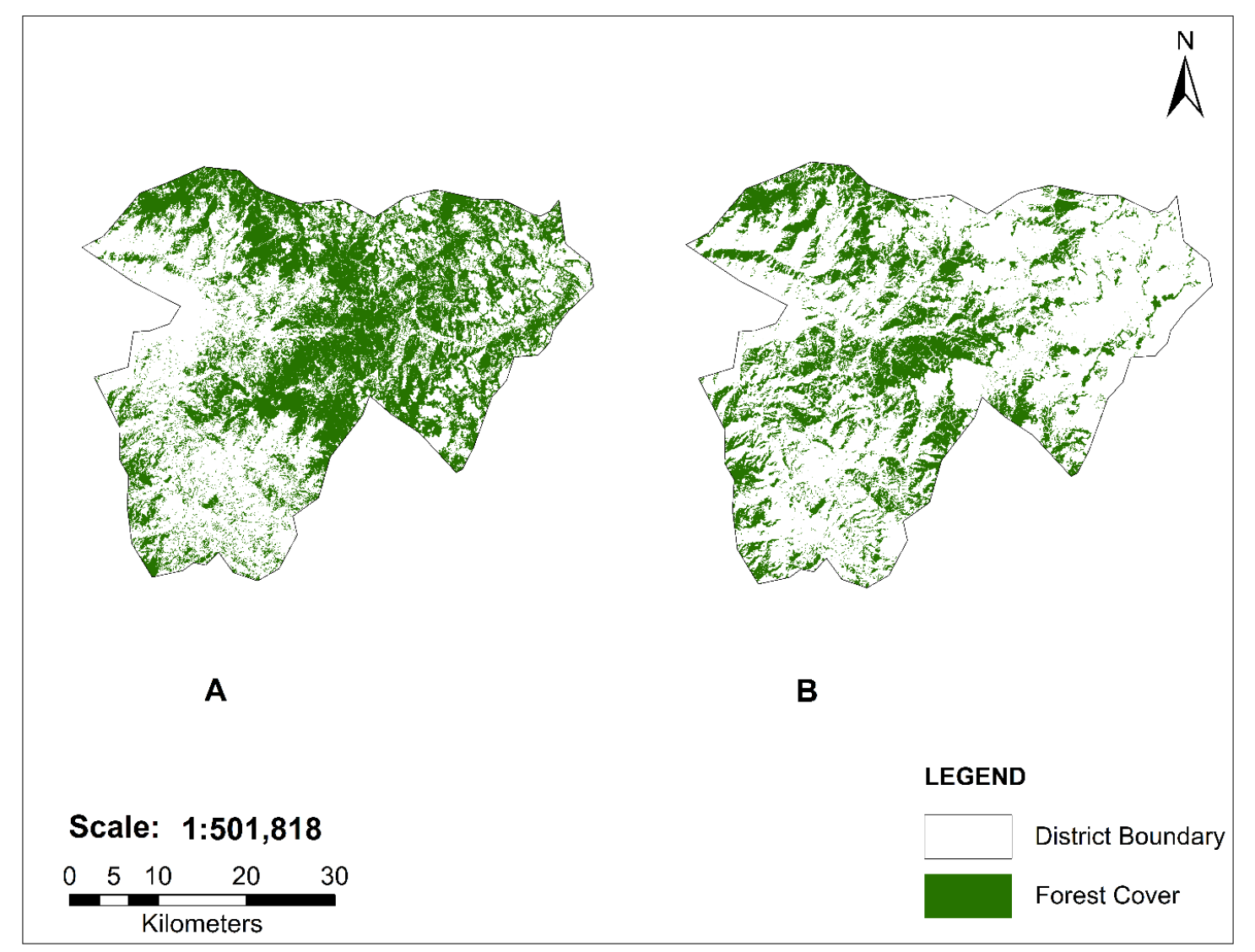

Figure 4. Study area forest cover map for the year 2000 (A) extracted from land use/cover map of 2000 and study area forest cover map for the year 2015 (B) extracted from land use/cover map of 2015 using conversion tool from raster to polygon and then dissolve tool in ArcMap 10.5.1

\section{Validation of land use land cover map}

LULC maps were validated using user's accuracy, producer's accuracy, kappa statistics and overall classification accuracy. 49 points were distributed randomly on each year imagery having seven classes. For each class there were seven points. Reference 
points and results of classification were compared from which error matrices created and with the help of these error matrices producer's users and overall accuracy of the classification was assessed. Overall classification accuracy ranges from $80.44 \%-86.24$ while overall kappa statistics ranges from 0.7621-0.8422. Accuracy results for each class can be seen in Table 1 which are in acceptable range. Accuracy of the year 2000 imagery is less because of the less spatial resolution imagery availability at Google Earth on our study area so it was difficult to discriminate between various classes.

Table 1. Accuracy assessment results of LULC map

\begin{tabular}{|c|c|c|c|c|c|c|c|c|}
\hline Years & Accuracy/classes & Glacier/snow & Water & $\begin{array}{c}\text { Barren } \\
\text { land }\end{array}$ & Settlement & $\begin{array}{l}\text { Shrub and } \\
\text { grassland }\end{array}$ & Agriculture & Forest \\
\hline \multirow{3}{*}{2000} & Producer's accuracy $(\%)$ & 71.54 & 90.54 & 68.77 & 65.31 & 89.23 & 74.19 & 86.79 \\
\hline & User's accuracy $(\%)$ & 69.14 & 95.13 & 73.15 & 71.73 & 88.71 & 75.97 & 89.25 \\
\hline & \multicolumn{3}{|c|}{ Overall classification accuracy (\%) 80.44} & \multicolumn{5}{|c|}{ Overall kappa statistics $=0.7621$} \\
\hline \multirow{3}{*}{2015} & Producer's accuracy $(\%)$ & 89.35 & 91.95 & 78.26 & 83.47 & 67.59 & 87.50 & 89.97 \\
\hline & User's accuracy (\%) & 87.73 & 97.79 & 81.35 & 85.71 & 79.53 & 77.59 & 93.97 \\
\hline & \multicolumn{4}{|c|}{ Overall classification accuracy (\%) 86.24} & \multicolumn{4}{|c|}{ Overall kappa statistics $=0.8422$} \\
\hline
\end{tabular}

\section{Biomass and carbon stock}

The major forest tree species found in the study area were Pinus wallichiana (Kail), Pinus roxberghii (Chir pine), Picea smithiana (Spruce), Abies pindrow (Fir), Cedrus deodara (Deodar) as well as some broadleaved species. Table 2 shows descriptive statistics of biomass, carbon stock and $\mathrm{CO} 2$ e (carbon dioxide equivalent) calculated from the field survey data collected from the 55 plots in the study area while Table A3 shows Biomass, Carbon Stock and $\mathrm{CO} 2$ e estimated per plot in the study area. The above ground biomass (AGB) ranged from 279.59 t/ha to $46.45 \mathrm{t} / \mathrm{ha}$ with a mean of $148.79 \mathrm{t} / \mathrm{ha}( \pm 40.77)$. The above ground carbon (AGC) ranged from $131.41 \mathrm{t} / \mathrm{ha}$ to $21.83 \mathrm{t} /$ ha with a mean of $69.93 \mathrm{t} / \mathrm{ha}( \pm 19.16)$. The denser the forest, the higher the value of biomass and carbon stock were. The $\mathrm{CO}_{2}$ e ranged from $606 \mathrm{t} / \mathrm{ha}$ to $100 \mathrm{t} / \mathrm{ha}$ with a mean of $322 \mathrm{t} / \mathrm{ha}( \pm 88.36)$. Total AGB in the study area was $6.7 \mathrm{Mt}$, and total BGB (below ground biomass) was $1.74 \mathrm{Mt}$ while the total Biomass (AGB + BGB) was 8.45 Mt. Similarly, the total AGC in the study area was 3.15 Mt and total BGC (below ground carbon) was $0.82 \mathrm{Mt}$ while the total Carbon (AGC + BGC) was $3.97 \mathrm{Mt}$. Finally, the total $\mathrm{CO}_{2}$ e in the study area was $14.53 \mathrm{Mt}$. According to Ahmad et al. (2014), the mean AGB and AGC in coniferous forests of Dir were found to be 258.98 $\mathrm{t} / \mathrm{ha}$ and $129.49 \mathrm{t} / \mathrm{ha}$, respectively. According to IPCC the range of AGB in the temperate forest is about 220 to $295 \mathrm{t} / \mathrm{ha}$ (IPCC, 2006). While according to Gairola et al. (2011), in the moist temperate forest of India the AGB ranges from 215.5-468.2 t/ha and AGC from 107.8-234.1 t/ha (Gairola et al., 2011). Similarly, Whittaker and Niering estimated AGB value in fir temperate forest which was 360-440 t/ha (Whittaker and Niering, 1975). The forest in our study area falls in the category of "Guzara Forest," and in guzara forest all the act are allowed until and unless prohibited by the government. Hence these are not reserved forests, the human interference and social pressure are more in these forests as compared to the reserved forest, as these have community rights. Therefore, more disturbance has been observed in these forests. 
Table 2. Descriptive summary statistics of biomass, carbon stock, and $\mathrm{CO}_{2}$ e

\begin{tabular}{c|c|c|c|c|c|c|c}
\hline Statistics & $\begin{array}{c}\text { AGB } \\
(\mathbf{t} / \mathbf{h a})\end{array}$ & $\begin{array}{c}\text { BGB } \\
(\mathbf{t} / \mathbf{h a})\end{array}$ & $\begin{array}{c}\text { Total biomass } \\
(\mathbf{t} / \mathbf{h a})\end{array}$ & $\begin{array}{c}\text { AGC } \\
(\mathbf{t} / \mathbf{h a})\end{array}$ & $\begin{array}{c}\text { BGC } \\
(\mathbf{t} / \mathbf{h a})\end{array}$ & $\begin{array}{c}\text { Total carbon } \\
(\mathbf{t} / \mathbf{h a})\end{array}$ & $\begin{array}{c}\mathbf{C O} \mathbf{e} \\
(\mathbf{t} / \mathbf{h a})\end{array}$ \\
\hline Sum & 8183.82 & 2127.79 & 10311.61 & 3846.39 & 1000.06 & 4846.46 & 17738.05 \\
Mean & 148.79 & 38.69 & 187.48 & 69.93 & 18.18 & 88.12 & 322.51 \\
St. Dev & 40.77 & 10.59 & 51.37 & 19.16 & 4.98 & 24.14 & 88.36 \\
St. Err & 5.49 & 1.43 & 6.93 & 2.58 & 0.67 & 3.25 & 11.92 \\
Min & 46.45 & 12.07 & 58.53 & 21.83 & 5.68 & 27.51 & 100.69 \\
Max & 279.59 & 72.69 & 352.29 & 131.41 & 34.16 & 165.58 & 606.02 \\
Range & 233.14 & 60.61 & 293.76 & 109.57 & 28.49 & 138.07 & 505.33 \\
Skewness & 0.72 & 0.72 & 0.72 & 0.72 & 0.72 & 0.72 & 0.72 \\
\hline
\end{tabular}

$\mathrm{AGB}=$ Above Ground Biomass, $\mathrm{BGB}=$ Below Ground Biomass, $\mathrm{AGC}=$ Above Ground Carbon, $\mathrm{BGC}=$ Below Ground Carbon, $\mathrm{CO}_{2} \mathrm{e}=$ carbon dioxide equivalent

\section{Relationship between biomass and vegetation indices}

Evaluating several vegetation indices is helpful when vegetation canopies are not uniform in terms of species which leads to complexity and variation in groundcover. Factors such as topography, background soil reflectance and variation in internal canopy signal scattering could interfere with final vegetation signal since in different ranges of biomass and groundcover different indices are more sensitive (Huete, 1988). In this regard twenty-five (25) vegetation indices were calculated and tested concerning its relationship with the biomass. Figure 5 shows eleven (11) vegetation indices which had a significant $(\mathrm{p} \leq 0.01)$ correlation with biomass. In comparison, narrowband red-edge vegetation indices performed better than the other types of indices. In the narrowband vegetation indices, RERVI had the highest $R$-square $\left(r^{2}=0.68 ; p \leq 0.01\right)$ while the NDII which is canopy water content VI had the lowest $\mathrm{R}$-square $\left(\mathrm{r}^{2}=0.16 ; \mathrm{p} \leq 0.005\right)$.

\section{Correlation between broadband vegetation indices and biomass}

Figure B1 (see Appendix) shows scatter plot graphs depicting relationships between biomass and various broadband vegetation indices. The R-square values of EVI, GNDVI, NDVI, SAVI, SQSR, and TSAVI were $0.29,0.33,0.28,0.28,0.21$, and 0.29 , respectively. The coefficients of the linear models between biomass and broadband vegetation indices were significant $(\mathrm{p} \leq 0.01)$. Since most of these indices (broadband VIs) use NIR and Red bands, therefore, sensor saturation issues were encountered especially in areas where there was dense and mature vegetation (Lu et al., 2012; Wang et al., 2016).

\section{Relationship between biomass and canopy water vegetation indices}

Figure B2 shows relationships between biomass and two canopy water indices, i.e. Normalized Difference Infrared Index (NDII) and Normalized Difference Water Index (NDWI). Significant relationships were found between biomass vs. NDII $\left(\mathrm{R}^{2}=0.16\right.$, $\mathrm{p} \leq 0.01)$ and NDWI $\left(\mathrm{R}^{2}=0.21, \mathrm{p} \leq 0.01\right)$. However, there $\mathrm{R}$-square values were mostly lower comparatively than the broadband vegetation indices since these indices use mostly the shortwave infrared bands of the sentinel sensor i.e. band $12(\lambda=1610 \mathrm{~nm})$ and band $13(\lambda=2190 \mathrm{~nm})$ which are more sensitive to water in the green vegetation than to the chlorophyll content. 


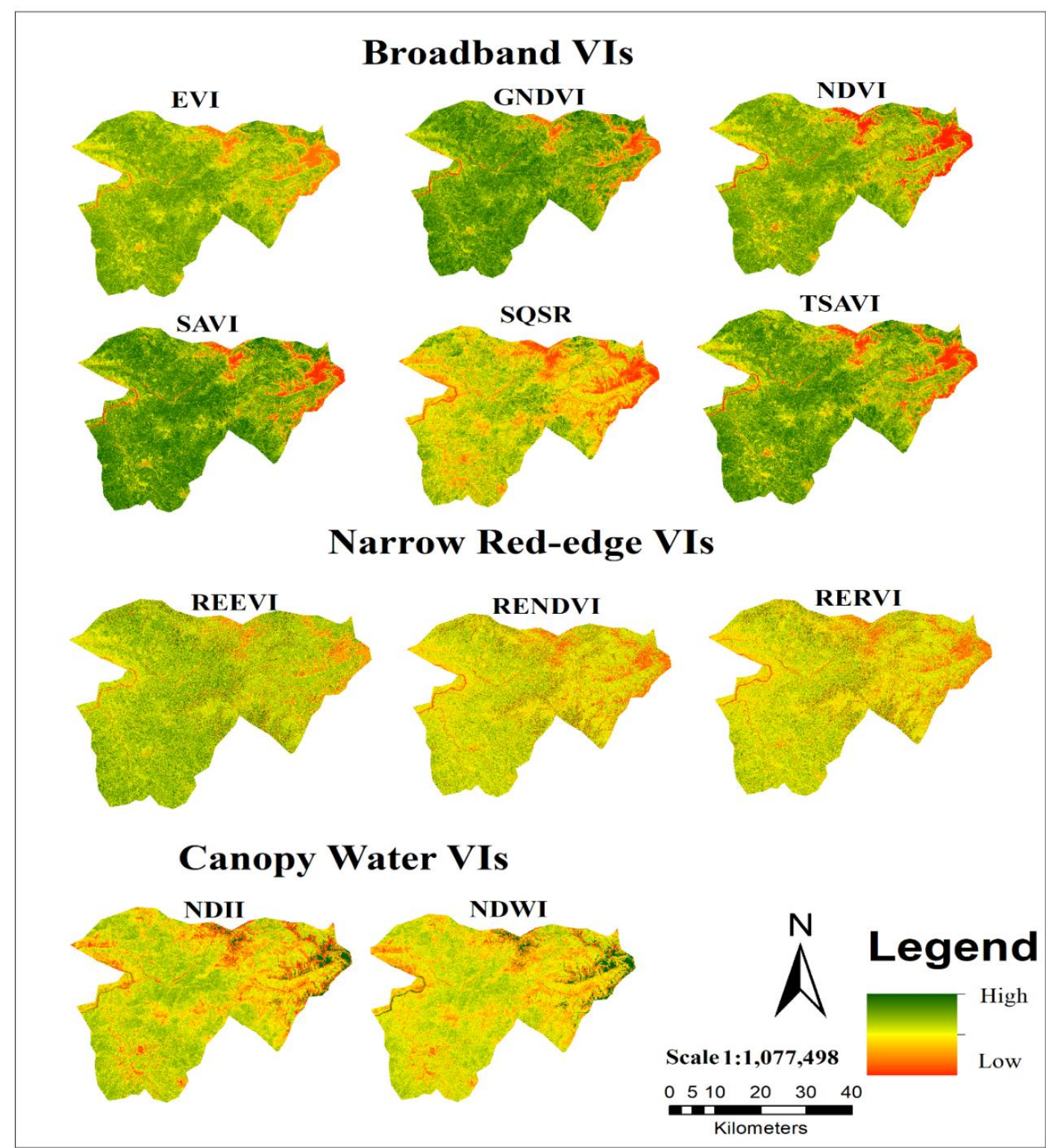

Figure 5. Broadband vegetation indices, narrow red-edge and canopy water vegetation indices derived from Sentinel-2 satellite imagery using their equations and distinct bands combination in ArcMap

\section{Relationship between biomass and narrow red-edge indices}

Using red-edge spectral bands VIs were calculated and saturation effects is decreased. Comparatively the red band $(\lambda=665 \mathrm{~nm})$ is known to have high absorptivity/sensitivity compared to the red-edge band $(\lambda=740 \mathrm{~nm})$. However, the rededge band remains to be sensitive to chlorophyll but to a moderate extent which reduces the saturation effects (Gitelson et al., 1996). Figure B3 shows relationships between biomass and red-edge vegetation indices, i.e. Red-edge Normalized Difference Vegetation Index (RENDVI), Red-edge Enhanced Vegetation Index (RE-EVI), and Red-edge Ratio Vegetation Index (RERVI). Due to narrow red-edge band, VIs saturation effect is reduced and the relationship of these indices with biomass was 
highly significant, and yielded higher R-square values. Higher relationships of biomass were found with RE-EVI, RE-NDVI and RERVI $\left(\mathrm{R}^{2}=0.67, \mathrm{p} \leq 0.01\right)$.

It can be deduced from the results of this study that red-edge bands are very useful in dense and mature forests where saturation has been reported to be a regular issue when using the red band in calculating the indices.

\section{Mapping spatial distribution of biomass}

Figure 6 shows spatial variability of predicted biomass using the forty-five (45) field surveyed data out of the fifty-five (55) total plot data. The remaining ten (10) biomass data was used for validation of the final biomass map. The best vegetation index was selected from the various indices which had the highest correlation coefficient and the lowest RMSE with field survey biomass data. A linear regression model was developed between RERVI and field surveyed 45 biomass data. The regression model was used in ArcMap's raster calculator tool to generate the final study area biomass map.

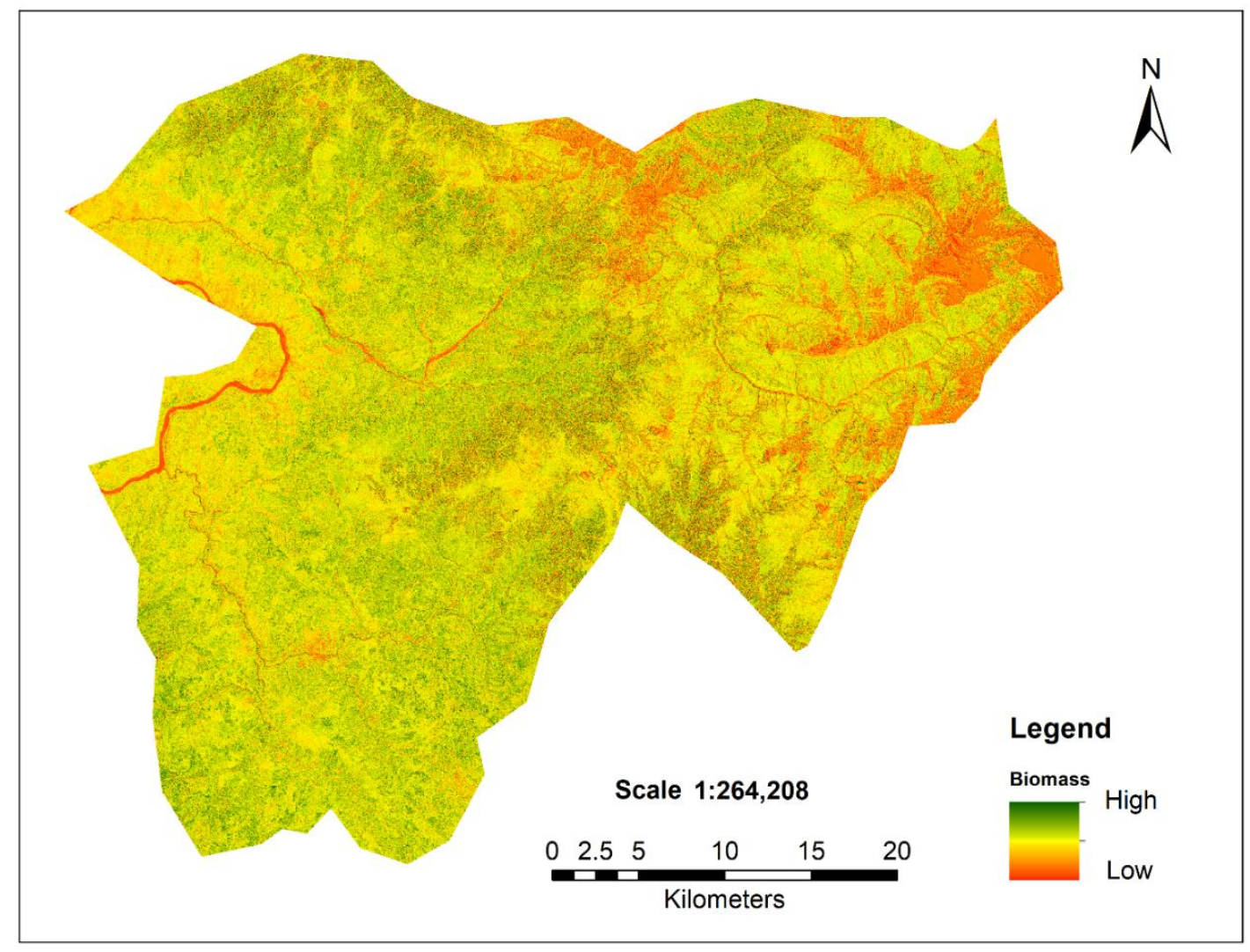

Figure 6. Study area biomass map derived from Sentinel-2 imagery best vegetation index (having high R-square, Low RMSE, and P-value less than 0.01) using its regression equation in ArcMap raster calculator from the best vegetation index (Red-edge Ratio Vegetation Index (RERVI)

\section{Accuracy of biomass map}

To evaluate how well the predicted biomass corresponds to the actual on-ground biomass, the remaining ten (10) ground surveyed data points were overlaid on the 
predicted biomass map and data was extracted for statistical comparison. A significant $(\mathrm{p} \leq 0.01) \mathrm{R}$-square $=0.67$ with an RMSE $=35.23 \mathrm{t} / \mathrm{ha}$ was found between the observed and predicted biomass which validates the final biomass map.

\section{Calculation of carbon emissions}

Emission factor determined was equal to $255.94 \mathrm{tCO}_{2} \mathrm{e} / \mathrm{ha}$, and in fifteen years carbon emissions were about $6.96 \mathrm{Mt} \mathrm{CO}_{2} \mathrm{e}$.

$$
\begin{gathered}
\text { Emission Factor }=69.93 \times 3.66 \\
\text { Emission Factor }=255.94 \mathrm{tCO}_{2} \mathrm{e} / \mathrm{ha}
\end{gathered}
$$

Activity data means a change in forest cover as we have already calculated the change in forest cover from 2000-2015 through remote sensing.

Activity data $=27209.64$ ha

By putting these values in the equation we get:

$$
\begin{gathered}
\mathrm{CE}=\mathrm{AD} \times \mathrm{EF} \\
\mathrm{CE}=27209.64 \times 255.94 \\
\mathrm{CE}=6964138.66 \mathrm{t} \mathrm{CO}_{2} \mathrm{e} \\
\mathrm{CE}=6.96 \mathrm{Mt} \mathrm{CO}_{2} \mathrm{e}
\end{gathered}
$$

\section{Carbon sequestration potential}

For our study area, which is a temperate forest, the $\mathrm{C}$ sequestration potential was calculated using the following formula:

$$
\begin{aligned}
& \text { Carbon Sequestration Potential (CSP) }=\text { Carbon Carrying Capacity (CCC) - Carbon Density (CD) } \\
& \text { CSP }=(152 \pm 13)^{*}-(69.93)=82.07 \pm 13 \mathrm{t} / \mathrm{ha}
\end{aligned}
$$

(Divide this value by the age of forest)

$$
\mathrm{CSP}=82.07 \pm 13 \mathrm{t} / \mathrm{ha} \div 100 \text { years }=0.82 \pm 0.13 \mathrm{t} / \mathrm{ha} / \text { year }
$$

(When forest age is assumed to be 100 years at maturity)

*This is a generic value of carbon carrying capacity (CCC) for the moist temperate forests (Yingchun et al., 2012).

The carbon sequestration potential estimated for the study area was $82.07 \mathrm{t} / \mathrm{ha} \pm$ $13 \mathrm{t} / \mathrm{ha}$. Hence the temperate forest possesses carbon sequestration potential up to $82.07 \mathrm{t} / \mathrm{ha} \pm 13 \mathrm{t} / \mathrm{ha}$. If we assume the rotation age of the forest to be hundred (100) years then the carbon sequestration potential will be $0.82 \pm 0.13 \mathrm{t} / \mathrm{ha} / \mathrm{year}$. It means that the forest can sequestrate about $0.82 \pm 0.13$ tons of carbon per hectare in a year. 


\section{Discussion}

Our study finding suggests that during the last fifteen-year deforestation had occurred at an alarming rate. The forested area has been mainly converted into agricultural land for food production. Subsequently, the $\mathrm{CO}_{2}$ e emission rate is comparatively very high during the reporting period. Since the study area falls within the "Guzara forest" (forest with community rights) which mandate the resident's rights to the forest wood for fuel and construction purpose. The deforestation rate could be reduced to a sustainable level and carbon sequestration potential can be enhanced by providing residents with alternative sources of energy and building construction material as well as through sustainable forest management practices. The REDD+ incentive should be extended to locals for carbon crediting and reforestation of the deforested area. Furthermore, our finding suggests that the narrowband rededge vegetation indices (RE-EVI, RENDVI and RERVI) performed better in the estimation of forest biomass as compared to broadband vegetation indices (EVI, GNDVI, NDVI, SAVI, SQSR and TSAVI) and canopy water vegetation indices (NDII and NDWI). Among the narrowband red-edge vegetation indices, RERVI performed the best in biomass estimation. Image of vegetation indices shows us less saturation in narrow band red-edge indices as compared to canopy water content and broad band VIs.

\section{Landuse landcover change detection}

Activity data means change occurred in the forest area. For land use change the Landsat-7 and Landsat-8 data was used. Data was downloaded from USGS earthexplorer website (Earthexplorer.usgs.gov) of June month for the year 2000 and for the month of September for 2015. These months images were downloaded because the vegetation is mostly visible having less cloud and snow cover. In erdas imagine 2015 supervised classification algorithm was applied for the assessment of land cover classes and to find change in the forest cover which had occurred in the last fifteen years. Landsat had a coarse resolution so it is difficult to correctly classify various land cover classes so for this purpose we connected the erdas imagine with google earth pro so when we go to the particular area on satellite imagery the google earth automatically goes to that place on that particular date and hence it is easy to classify various land features then. Spectral signatures were taken for particular classes and more than five hundred signatures were taken for single class using maximum likelihood algorithm, supervised classification was applied and thematic map of seven major classes was obtained (Glacier and Snow, Water, Barren Land, Settlement, Shrub and Grassland, Agriculture, Forest). After classification manual correction were done using recode option in Erdas imagine then mean filter was applied and finally accuracy assessment was done. Major decreasing change was observed in the forest (-16.9\%) and barren land $(-7.7 \%)$ while agricultural area was increased $(12.2 \%)$. There was no significant change in settlement $(0.3 \%)$ so the major cause of deforestation could be illegal logging. The annual deforestation rate was $2.51 \%$.

\section{Above ground biomass/carbon stock estimation}

Above ground biomass was estimated in field through forest inventory (DBH and Height) and using allometric equations. Mean AGB of $148.79 \mathrm{t} / \mathrm{ha}$ was obtained which was then converted to carbon stock through a conversion factor and the mean value of 
above ground carbon stock obtained was 69.93 t/ha. From sentinel-2 imagery several type of VIs indices were calculated and finally to assess the relationship between AGB and vegetation indices linear regression model was developed. Thus, the forest biomass was calculated by both methods (field inventory and remote sensing) and biomass map was validated from the field data.

\section{Correlation between AGB and VIs}

Relationship between AGB and VIs was assessed using linear regression model. In this study three categories of vegetation indices; broad band, canopy water content and narrow red-edge band VIs were used. These categories of indices were assessed in our study area as these have effect on assessment of above ground biomass performance and accuracy. Four different types of bands were used in the computation of these vegetation indices consisting of Red, Near Infrared (NIR), Short Wave Infrared (SWIR) and Red-edge bands.

\section{Correlation between AGB and broadband VIs}

Broadband VIs and AGB had weak relationship. The VIs includes EVI, GNDVI, NDVI, SAVI, SQSR and TSAVI. Our results of broadband VIs are similar to that of Mcmorrow et al. (Foody et al., 2001), according to which relationship between biomass and NDVI is poor. Using Landsat TM derived NDVI AGB was estimated by Mganga and Lyaruu (2015) in Mgaraganza and Kitwe forest areas of Tanzania. From the results we see in both areas $r^{2}$ of 0.22 and 0.23. Nugroho (2006) assessed the relationship between VIs and AGB, $\mathrm{r}^{2}$ value was 0.21 for EVI and 0.14 for NDVI. The main reason of less accuracy was saturation problem.

There are two main reasons of saturation, one is crops maturity (Mutanga and Skidmore, 2004a; Wang et al., 2016) while the other is due to complex forest structure (Lu et al., 2016; Sinha et al., 2016). Due to saturation VIs cannot sense increase in biomass and it occurs when the area is covered fully by leaves or vegetation fully covers the land. So the indices values do not change while the biomass continues to increase. According to Wang (Wang et al., 2016) saturation occurs due to the reason that Vegetation indices are computed using NIR and red spectral band $(680 \mathrm{~nm})$. So electromagnetic spectrum radiations are absorbed by the red band and it does not increase continuously with increase in canopy cover due to the reason that when canopy closure is at $100 \%$ the amount of red energy absorbed reaches to peak. Besides this, due to multiple scattering the reflectance of NIR increases when canopy reaches $100 \%$ (Thenkabail et al., 2000). Therefore, in broad band indices ratio (EVI, SAVI, NDVI) an inequality is being caused because of increase in NIR band and decrease in red absorption band hence results are poor in the assessment of biomass (Mutanga and Skidmore, 2004a).

\section{Correlation between AGB and canopy water content VIs}

Relationship of AGB and canopy water content index was very weak with an $\mathrm{r}^{2}$ of 0.16 for NDII and 0.22 for NDWI. Using SWIR bands canopy water content VIs computation was done ( $\mathrm{Lu}$ et al., 2016). As canopy cover increases the water content also increases in leaf. Less research has been conducted on biomass estimation from canopy water content VIs. 


\section{Correlation between AGB and narrow red-edge VIs}

Using band 6 of Sentinel-2 image which is a red-egde band of $740 \mathrm{~nm}$ wavelength and NIR band narrow red-edge VIs were calculated. Relationship between AGB and red edge VIs is the highest. The $\mathrm{r}^{2} 0.68$ of RERVI was the highest. Narrow red-edge Vegetation Indices outperform the other two categories. Because the red-edge spectral band is between NIR and red region which is a high cholophyll absorption and reflectance area. Therefore, the variations in leaf properties and chlorphyll highly affect the red-edge spectral bands (Slonecker et al., 2009). The red-edge and NIR (700 nm to $1300 \mathrm{~nm}$ ) part of reflectance is higher (about 60\%) while red region (500 to $700 \mathrm{~nm}$ ) reflects less than 30\% (Gitelson and Merzlyak, 1997). Several studies (Chen et al., 2007b; Zhao et al., 2007) were conducted to compare the performance of VIs (NDVI, EVI, SR) using NIR and red bands with red-edge bands. From the results we can see that relationship of red-edge indices were better as it improves the $r^{2}$ significantly than that of red band. Relationship between VIs derived from World-View 2 was assessed by Winmore (2012) for carbon stock estimation in the forests of south Africa. In this study mutual comparison of standard vegetation indices (NDVI, SAVI, SR) and red-edge indices (NDVI-RE, SAVI-RE and SR-RE) was conducted through simple linear regression. From the results it was concluded that using red-edge band the $\mathrm{r}^{2}$ increased which concludes that carbon stock estimation accuracy was improved by red-edge band. According Mutanga et al. (2012) RENDVI performed better having an $r^{2}$ of 0.67 in comparison with standard NDVI having $\mathrm{r}^{2}$ of 0.39 . In these studies, the Standard NDVI performance were a bit high than those of our results because of medium spatial resolution $(10 \mathrm{~m})$ of sentinel-2 imagery than that of World-View-2 images $(2 \mathrm{~m})$ as we know from previous studies that on performance of VIs spatial resolution have an influence on the estimation of biomass (Gara et al., 2017). Besides this saturation problem is less in simple forest structure than that of complex forest structure.

\section{Mapping spatial distribution of biomass}

The biomass map shows a denser forest biomass in the northwestern and low in the northeastern quadrant of the study area so more dissimilarities are observed in the northeastern side of the study area due to less forest cover resulting in significant variation in the biomass (Chi et al., 2015). The lowest biomass could be due to the highest altitude of the study area as above $3500 \mathrm{~m}$ elevation there are subalpine and alpine pastures, so the biomass was found to be the lowest. Using remotely sensed optical data for biomass mapping have specific limitation such as if we use it in open tree canopy cover and near snow then it underestimates the biomass in both cases (Karlson et al., 2015). Also in the assessment of vegetation cover from optical data, there are more chances of neglecting little trees (Karlson et al., 2014). The openness in the forest maybe due to high anthropogenic activities related to illegal logging etc.

The overall spatial variability in the biomass could be due to different species occurrence, i.e. Pinus roxberghii (chir pine), Pinus wallichiana (Kail), Pinus gerardiana (Chilghoza), Abies pindrow (Fir), Picea smithiana (Spruce), Cedrus deodara (Deodar) and Quercus spp (Oak) in the study area. This could result in the variation of the final biomass while the biomass in coniferous species will be higher than that of broadleaved species because of its high wood density, volume, and age. Biomass also depends on the age of tree species; therefore, the younger trees have lower biomass while the mature trees have higher biomass. Northern aspect is cool and has more moisture and 
vegetation cover; therefore, biomass could also be high on the northern aspect while the southern aspect is warmer having less moisture and vegetation cover, therefore, resulting in low biomass. The denser the vegetation and crown cover are the higher the biomass will be (Du et al., 2014).

\section{Calculation of carbon emission}

The historical forest inventory data was not available with the local forest department. Therefore, we assumed the year 2000 carbon stock data to be the same as carbon stock of 2015 (69.93) to calculate the carbon emission.

In our case, the forest acts as a source of carbon not sink. Forests are not protected according to forests policy, and forest law enforcement is also very weak due to which illegal logging and wood harvesting occur. Emissions of $\mathrm{CO}_{2}$ results increased due to land-use change because of deforestation which is a major cause of climate change. According to Houghton (2003), on a global scale, the deforestation contributes about $156 \mathrm{Pg}$ of carbon emitted to the atmosphere from 1850 to 2005 and $12 \%$ to $15 \%$ of total emissions of GHG. Our results suggest $6.96 \mathrm{MtCO}_{2}$ e contributed to the atmosphere from our study area during the 15 years (2000-2015). Since due to deforestation carbon is not only lost to the atmosphere but the mechanism of $\mathrm{CO}_{2}$ absorption by trees is also eliminated (Rokityanskiy et al., 2007). Degradation and deforestation may be due to disease, flood, fire, and storm, (natural causes) while it may also be due to illegal wood harvesting, expansion of agriculture, government policies, development of infrastructure, poverty, as well as the cultural attitude that changed towards the forest (Keenan et al., 2015).

\section{Carbon sequestration potential}

To mitigate the atmospheric $\mathrm{CO}_{2}$ effectively, one has to quantify the $\mathrm{C}$ sequestration potential of all $\mathrm{C}$ pools including a forest in order to best estimate its contribution. For example, when the forest is in the developmental stage, then the $\mathrm{C}$ storage capacity could be manifold, and it will act as a sink of $\mathrm{C}$ while the old forest (80-100 years age) stores carbon very slowly. So for reducing carbon emission, we should attain carbon carrying capacity and decrease human disturbance in our forests. The forest sequestration potential can be enhanced through afforestation, reforestation activities, reducing the anthropogenic activities as well using sustainable forest management practices.

\section{Remote sensing applicability for REDD+ implementation}

In third world countries where check and balance systems of monitoring are not adhered to fulfill the requirements of the international obligations, the RS techniques can play a critical and decisive role in successful forest activities monitoring and implementation of the REDD+ system at local and national spatial scales. The remote sensing technique for monitoring and implementation seems to be the best, costeffective and accurate method for the assessment of carbon stock, biomass, and carbon emission. From our results, the VIs derived from Sentinel-2 are implicit for the assessment of carbon stock and the biomass as well. Besides this, the Sentinel-2 imagery is multi-spectral having 13-bands consisting of SWIR and Red-edge spectral bands and is freely available. As compared to other medium resolution satellite imageries it has $10 \mathrm{~m}$ spatial resolution which is high. The availability of Red-edge 
band reduces the saturation problem. The method adopted in this study is feasible and could be applied on a larger spatial scale, i.e. at the regional and national level. For the assessment of forest cover change and carbon emission estimation Landsat open source and historic data increase its importance. Hence this study will serve REDD+ in its objective of sustainable forest management and reducing $\mathrm{CO}_{2}$ emissions.

\section{Study limitation and recommendation for future research}

In Sentinel-2 satellite imagery, not all the spectral bands are of the same resolution, i.e. some of the bands are of $10 \mathrm{~m}$ resolution while others are of $20 \mathrm{~m}$. In order to make all the bands of the same resolution $(10 \mathrm{~m})$, we had to resample the data due to which the accuracy of estimation of biomass from VIs might have been affected as some of the spectral information might be lost due to resampling. Use of high-resolution optical data both for the assessment of deforestation, degradation as well as biomass and carbon stock can further increase the accuracy of the results.

In the future, research is required on the integration of optical and RADAR data since optical data do not take into account the below canopy vegetation which could result in an underestimation of above ground biomass. This issue can be resolved by incorporating the RADAR data that could also reduce sensor saturation in opticalsensor images. Launching of additional advanced satellite sensors are required which are specifically designed for terrestrial carbon stock monitoring and particularly that of spaceborne LiDAR sensor. Hence LiDAR data use can further increase the accuracy.

Use of historical ground data can improve our understanding of carbon emission estimation. For a better insight of variation in carbon stock of forest ecosystem and carbon emissions, spatiotemporal analysis of carbon fluxes studies needs to be carried out. Furthermore, carbon sequestration potential can be assessed with better accuracy, if climatic variables (precipitation, temperature) and old-growth forest data are available (Cramer et al., 2001).

Farm forestry, agroforestry practices and technologies of clean energy should help in the reduction of carbon emissions. For sustainable forest management and climate change, clean development mechanism as well as UN REDD+ program could be helpful.

\section{Conclusions}

From this study, we conclude that forest land is decreased at an alarming rate because of increase in agricultural land, shrub/grassland and urban areas and about $16.88 \%$ of forest area is lost in fifteen years. The annual deforestation rate is $2.51 \%$ and due to deforestation carbon emissions were about $6.96 \mathrm{Mt} \mathrm{CO}_{2}$ e in fifteen years. Natural forests are cleared for agricultural purpose due to which the ecology of the region is disturbed. To decrease carbon emissions, the deforestation and degradation must be lessened through conservation of forest and sustainable management of the forest. AGB and carbon stock in the study area were $148.79 \mathrm{t} / \mathrm{ha}$ and $69.93 \mathrm{t} / \mathrm{ha}$. VIs derived from sentinel-2 imagery have the potential in the estimation of biomass. Saturation problem leads to poor estimation of AGB in canopy water content and broadband Vis. However, red-edge band reduces the saturation problem and thus it is more appropriate. Therefore, in future red-edge VIs should be used for biomass estimation instead of broadband VIs. Spatial distribution of biomass was mapped from 
the best VI and validated with the ground data which is much important in order to know management, disturbance and carbon fluxes in the forest. Carbon sequestration potential was $82.07 \mathrm{t} / \mathrm{ha} \pm 13 \mathrm{t} / \mathrm{ha}$.

For better forest management, remote sensing and GIS should also be applied with ground forestry operations and in the estimation of biomass, carbon stock and carbon emissions the use of remotely sensed data such as Vegetation Indices. This can decrease labor force. The ground data can be applied on a large scale, i.e. at regional and national level through remote sensing. From the study, we can see that biomass and carbon stock can be estimated with better accuracy from vegetation indices derived from sentinel-2 imagery as compared to other sensors because of its high spatial resolution $(10 \mathrm{~m})$ as well as spectral bands for vegetation study.

The areas which are inaccessible and ground survey is difficult to be performed so this method is more suitable for biomass and carbon stock estimation. Hence this method seems to be the most cost-effective, best and most accurate for the assessment of biomass, carbon stock, change in forest cover and carbon emissions. This study will serve REDD+ in its objective of sustainable forest management and lessening emission of $\mathrm{CO}_{2}$ in the atmosphere.

Acknowledgments. The authors acknowledge the financial support of National University of Sciences and Technology (NUST) for publishing this work. The authors are also very grateful to Pakistan Forest Institute (PFI), Peshawar for providing support and help in field data collection.

Funding. This research received no external funding.

Conflict of interests. The authors declare no conflict of interests.

\section{REFERENCES}

[1] Abdel-Rahman, E. M., Landmann, T., Kyalo, R., Ong'amo, G., Mwalusepo, S., Sulieman, S., Le Ru, B. (2017): Predicting stem borer density in maize using RapidEye data and generalized linear models. - International Journal of Applied Earth Observation and Geoinformation 57: 61-74.

[2] Ahmad, A., Mirza, S. N., Nizami, S. (2014): Assessment of biomass and carbon stocks in coniferous forest of Dir Kohistan, KPK. - Pakistan Journal of Agricultural Sciences 51: 35-350.

[3] Ali, A. (2015): Biomass and Carbon Tables for Major Tree Species of Gilgit Baltistan, Pakistan. - Gilgit-Baltistan Forests, Wildlife and Environment Department, Gilgit.

[4] Ali, A., Ullah, S., Bushra, S., Ahmad, N., Ali, A., Khan, M. A. (2018): Quantifying forest carbon stocks by integrating satellite images and forest inventory data. (Quantifizierung der Kohlenstoffvorräte in Wäldern durch die Integration von Satellitenbildern und Waldinventurdaten.) - Austrian Journal of Forest Science 2018(2): 93-17

[5] Angelsen, A. (2009): Realising REDD+: National Strategy and Policy Options. - CIFOR, Bogor Barat, Indonesia.

[6] Aslam, A., Amir, P., Ramay, S., Munawar, Z., Ahmad, V. (2011): National Economic and Environmental Development Study (NEEDS). - UNFCCC.

[7] Asner, G. P. (2001): Cloud cover in Landsat observations of the Brazilian Amazon. International Journal of Remote Sensing 22: 3855-3862.

[8] Baillarin, S., Meygret, A., Dechoz, C., Petrucci, B., Lacherade, S., Tremas, T., Isola, C., Martimort, P., Spoto, F. (2012): Sentinel-2 level 1 products and image processing performances. Geoscience and Remote Sensing Symposium (IGARSS). - IEEE International 2012: 7003-7006. 
[9] Balderas Torres, A., Skutsch, M. (2012): Splitting the difference: a proposal for benefit sharing in reduced emissions from deforestation and forest degradation (REDD+). Forests 3: 137-154.

[10] Baral, S. (2011): Mapping carbon stock using high resolution satellite images in subtropical forest of Nepal. - Unpublished, University of Twente (ITC), Enschede. http://www.itc.nl/library/papers_2011/msc/nrm/baral. pdf.

[11] Baret, F., Guyot, G. (1991): Potentials and limits of vegetation indices for LAI and APAR assessment. - Remote sensing of environment 35: 161-173.

[12] Brown, S. (2002): Measuring carbon in forests: current status and future challenges. Environmental pollution 116: 363-372.

[13] Cao, Q., Miao, Y., Shen, J., Yu, W., Yuan, F., Cheng, S., Huang, S., Wang, H., Yang, W., Liu, F. (2016): Improving in-season estimation of rice yield potential and responsiveness to topdressing nitrogen application with Crop Circle active crop canopy sensor. Precision agriculture 17: 136-154.

[14] Caparros, A., Ovando, P., Oviedo, J. L., Campos, P. (2011): Accounting for carbon in avoided degradation and reforestation programmes in Mediterranean forests. Environment and Development Economics 16: 405-428.

[15] Chave, J. R., Andalo, C., Brown, S., Cairns, M. A., Chambers, J., Eamus, D., Fölster, H., Fromard, F., Higuchi, N., Kira, T. (2005): Tree allometry and improved estimation of carbon stocks and balance in tropical forests. - Oecologia 145: 87-99.

[16] Chavez Jr, P. S. (1988): An improved dark-object subtraction technique for atmospheric scattering correction of multispectral data. - Remote sensing of environment 24: 459-479.

[17] Chavez, P. S. (1996): Image-based atmospheric corrections-revisited and improved. Photogrammetric Engineering and Remote Sensing 62: 1025-1035.

[18] Chen, J.-C., Yang, C.-M., Wu, S.-T., Chung, Y.-L., Charles, A. L., Chen, C.-T. (2007a): Leaf chlorophyll content and surface spectral reflectance of tree species along a terrain gradient in Taiwan's Kenting National Park. - Bot Stud 48: 71-77.

[19] Chen, J.-C., Yang, C.-M., Wu, S.-T., Chung, Y.-L., Charles, A. L., Chen, C.-T. (2007b): Leaf chlorophyll content and surface spectral reflectance of tree species along a terrain gradient in Taiwan's Kenting National Park. - Stud 48: 71-77.

[20] Chi, H., Sun, G., Huang, J., Guo, Z., Ni, W., Fu, A. (2015): National forest aboveground biomass mapping from ICESat/GLAS data and MODIS imagery in China. - Remote Sensing 7: 5534-5564.

[21] Cramer, W., Bondeau, A., Woodward, F. I., Prentice, I. C., Betts, R. A., Brovkin, V., Cox, P. M., Fisher, V., Foley, J. A., Friend, A. D. (2001): Global response of terrestrial ecosystem structure and function to $\mathrm{CO} 2$ and climate change: results from six dynamic global vegetation models. - Global Change Biology 7: 357-373.

[22] Delegido, J., Verrelst, J., Alonso, L., Moreno, J. (2011): Evaluation of sentinel-2 red-edge bands for empirical estimation of green LAI and chlorophyll content. - Sensors 11: 70637081.

[23] Dobbs, C., Kendal, D., Nitschke, C. R. (2014): Multiple ecosystem services and disservices of the urban forest establishing their connections with landscape structure and sociodemographics. - Ecological Indicators 43: 44-55.

[24] Du, L., Zhou, T., Zou, Z., Zhao, X., Huang, K., Wu, H. (2014): Mapping forest biomass using remote sensing and national forest inventory in China. - Forests 5: 1267-1283.

[25] Dube, F., Espinosa, M., Stolpe, N. B., Zagal, E., Thevathasan, N. V., Gordon, A. M. (2012): Productivity and carbon storage in silvopastoral systems with Pinus ponderosa and Trifolium spp., plantations and pasture on an Andisol in Patagonia, Chile. Agroforestry systems 86: 113-128.

[26] Egenhofer, C. (2007): The Making of the EU Emissions Trading Scheme:: Status, Prospects and Implications for Business. - European Management Journal 25: 453-463.

[27] FAO (2014): 2015 Forest Resource Assessment for Pakistan. Country Report Pakistan. FAO, Rome. 
[28] FCPF (Forest Carbon Partnership Facility) (2013): Readiness Preparation Proposal (RPP) for Country: Pakistan. Country Submission. - The UN Collaborative Programme on Reducing Emissions from Deforestation and Forest Degradation in Developing Countries (UN-REDD).

[29] Fernández-Manso, O., Fernández-Manso, A., Quintano, C. (2014): Estimation of aboveground biomass in Mediterranean forests by statistical modelling of ASTER fraction images. - International Journal of Applied Earth Observation and Geoinformation 31: 45-56.

[30] Foody, G. M., Cutler, M. E., Mcmorrow, J., Pelz, D., Tangki, H., Boyd, D. S., Douglas, I. (2001): Mapping the biomass of Bornean tropical rain forest from remotely sensed data. Global Ecology and Biogeography 10: 379-387.

[31] Gairola, S., Sharma, C., Ghildiyal, S., Suyal, S. (2011): Live tree biomass and carbon variation along an altitudinal gradient in moist temperate valley slopes of the Garhwal Himalaya (India). - Current Science 1862-1870.

[32] Gao, B.-C. (1996): NDWI-A normalized difference water index for remote sensing of vegetation liquid water from space. - Remote Sensing of Environment 58: 257-266.

[33] Gao, X., Jiang, Z., Guo, Q., Zhang, Y., Yin, H., He, F., Qi, L., Shi, L. (2015): Allometry and biomass production of phyllostachys edulis across the whole lifespan. - Polish Journal of Environmental Studies 24(2): 511-517.

[34] Gao, X., Li, Z., Yu, H., Jiang, Z., Wang, C., Zhang, Y., Qi, L., Shi, L. (2016): Modeling of the height-diameter relationship using an allometric equation model: a case study of stands of Phyllostachys edulis. - Journal of Forestry Research 27: 339347.

[35] Gara, T. W., Murwira, A., Dube, T., Sibanda, M., Rwasoka, D. T., Ndaimani, H., Chivhenge, E., Hatendi, C. M. (2017): Estimating forest carbon stocks in tropical dry forests of Zimbabwe: exploring the performance of high and medium spatial-resolution multispectral sensors. - Southern Forests: a Journal of Forest Science 79: 31-40.

[36] Gibbs, H. K., Brown, S., Niles, J. O., Foley, J. A. (2007): Monitoring and estimating tropical forest carbon stocks: making REDD a reality. - Environmental Research Letters 2: 045023.

[37] Gitelson, A. A., Merzlyak, M. N. (1997): Remote estimation of chlorophyll content in higher plant leaves. - International Journal of Remote Sensing 18: 2691-2697.

[38] Gitelson, A. A., Kaufman, Y. J., Merzlyak, M. N. (1996): Use of a green channel in remote sensing of global vegetation from EOS-MODIS. - Remote sensing of Environment 58: 289-298.

[39] Gizachew, B., Solberg, S., Næsset, E., Gobakken, T., Bollandsås, O. M., Breidenbach, J., Zahabu, E., Mauya, E. W. (2016): Mapping and estimating the total living biomass and carbon in low-biomass woodlands using Landsat $8 \mathrm{CDR}$ data. - Carbon Balance and Management 11: 13. https://doi.org/10.1186/s13021-016-0055-8.

[40] Houghton, R. A. (2003): Revised estimates of the annual net flux of carbon to the atmosphere from changes in land use and land management 1850-2000. - Tellus B 55: 378-390.

[41] Hudiburg, T., Law, B., Turner, D. P., Campbell, J., Donato, D., Duane, M. (2009): Carbon dynamics of Oregon and Northern California forests and potential land-based carbon storage. - Ecological applications 19: 163-180.

[42] Huete, A. R. (1988): A soil-adjusted vegetation index (SAVI). - Remote Sensing of Environment 25: 295-309.

[43] Hunt, E. R., Wang, L., Qu, J. J., Hao, X. (2012): Remote sensing of fuel moisture content from canopy water indices and normalized dry matter index. - Journal of Applied Remote Sensing 6: 061705.

[44] Intergovernmental Penal on Climate Change (IPCC) (2006): IPCC Guidelines for National Greenhouse Gas Inventories. Vol. 5. Waste. - Prepared by the National Greenhouse Gas Inventories Programme, IGES, Japan. 
[45] Itkonen, P. (2012): Estimating leaf area index and aboveground biomass by empirical modeling using Spot HRVIR satellite imagery in the Taita Hills, SE Kenya. - Thesis, University of Helsinki, Faculty of Mathematics and Science, Department of Geosciences and Geography.

[46] Jackson, R. B., Baker, J. S. (2010): Opportunities and constraints for forest climate mitigation. - BioScience 60: 698-707.

[47] Jiang, Z., Huete, A. R., Didan, K., Miura, T. (2008): Development of a two-band enhanced vegetation index without a blue band. - Remote Sensing of Environment 112: 3833-3845.

[48] Karki, S., Joshi, L., Karky, B. (2014): Learning on reducing emissions from deforestation and forest degradation. Regional Workshop, Kathmandu, Nepal, 24-27 July 2012. - International Centre for Integrated Mountain Development (ICIMOD), Lalitpur, Nepal.

[49] Karlson, M., Reese, H., Ostwald, M. (2014): Tree crown mapping in managed woodlands (parklands) of semi-arid West Africa using WorldView-2 imagery and geographic object based image analysis. - Sensors 14: 22643-22669.

[50] Karlson, M., Ostwald, M., Reese, H., Sanou, J., Tankoano, B., Mattsson, E. (2015): Mapping tree canopy cover and aboveground biomass in Sudano-Sahelian woodlands using Landsat 8 and random forest. - Remote Sensing 7: 10017-10041.

[51] Keenan, R. J., Reams, G. A., Achard, F., De Freitas, J. V., Grainger, A., Lindquist, E. (2015): Dynamics of global forest area: results from the FAO Global Forest Resources Assessment 2015. - Forest Ecology and Management 352: 9-20.

[52] Keith, H., Mackey, B. G., Lindenmayer, D. B. (2009): Re-evaluation of forest biomass carbon stocks and lessons from the world's most carbon-dense forests. - Proceedings of the National Academy of Sciences 106: 11635-11640.

[53] Le Toan, T., Quegan, S., Davidson, M., Balzter, H., Paillou, P., Papathanassiou, K., Plummer, S., Rocca, F., Saatchi, S., Shugart, H. (2011): The BIOMASS mission: mapping global forest biomass to better understand the terrestrial carbon cycle. - Remote sensing of environment 115: 2850-2860.

[54] Lippke, B., Perez-Garcia, J., Manriquez, C. (2003): Executive Summary: The Impact of Forests and Forest Management on Carbon Storage. - Rural Technological Initiative, College of Forest Resources, University of Washington, Seattle.

[55] Liu, Y., Wang, Q., Yu, G., Zhu, X., Zhan, X., Guo, Q., Yang, H., Li, S., Hu, Z. (2011): Ecosystems carbon storage and carbon sequestration potential of two main tree species for the Grain for Green Project on China's hilly Loess Plateau. - Shengtai Xuebao/Acta Ecologica Sinica 31: 4277-4286.

[56] Lu, D. (2005): Aboveground biomass estimation using Landsat TM data in the Brazilian Amazon. - International Journal of Remote Sensing 26: 2509-2525.

[57] Lu, D. (2006): The potential and challenge of remote sensing-based biomass estimation. International Journal of Remote Sensing 27: 1297-1328.

[58] Lu, D., Mausel, P., Brondizio, E., Moran, E. (2002): Above-Ground Biomass Estimation of Successional and Mature Forests Using TM Images in the Amazon Basin. - In: Richardson, D. E., van Oosterom P. (eds.) Advances in Spatial Data Handling. Springer, Berlin.

[59] Lu, D., Chen, Q., Wang, G., Moran, E., Batistella, M., Zhang, M., Vaglio Laurin, G., Saah, D. (2012): Aboveground forest biomass estimation with Landsat and LiDAR data and uncertainty analysis of the estimates. - International Journal of Forestry Research 2012.

[60] Lu, D., Chen, Q., Wang, G., Liu, L., Li, G., Moran, E. (2016): A survey of remote sensing-based aboveground biomass estimation methods in forest ecosystems. International Journal of Digital Earth 9: 63-105.

[61] Mcroberts, R. E., Tomppo, E. O., Næsset, E. (2010): Advances and emerging issues in national forest inventories. - Scandinavian Journal of Forest Research 25: 368-381. 
[62] Melville, G., Stone, C., Turner, R. (2015): Application of LiDAR data to maximise the efficiency of inventory plots in softwood plantations. - New Zealand Journal of Forestry Science 45: 9.

[63] Mganga, N., Lyaruu, H. (2015): Applicability of satellite remote sensing in accounting above-ground carbon in Miombo Woodlands. - International Journal of Advanced Remote Sensing and GIS 4: 1334-1343.

[64] Molto, Q., Rossi, V., Blanc, L. (2013): Error propagation in biomass estimation in tropical forests. - Methods in Ecology and Evolution 4: 175-183.

[65] Montes, N., Gauquelin, T., Badri, W., Bertaudiere, V., Zaoui, E. H. (2000): A nondestructive method for estimating above-ground forest biomass in threatened woodlands. - Forest Ecology and Management 130: 37-46.

[66] Mutanga, O., Adam, E., Cho, M. A. (2012): High density biomass estimation for wetland vegetation using WorldView-2 imagery and random forest regression algorithm. - International Journal of Applied Earth Observation and Geoinformation 18: 399-406.

[67] Mutanga, O., Skidmore, A. K. (2004a): Hyperspectral band depth analysis for a better estimation of grass biomass (Cenchrus ciliaris) measured under controlled laboratory conditions. - International Journal of Applied Earth Observation and Geoinformation 5: 87-96.

[68] Mutanga, O., Skidmore, A. K. (2004b): Narrow band vegetation indices overcome the saturation problem in biomass estimation. - International Journal of Remote Sensing 25: 3999-4014.

[69] Muukkonen, P., Heiskanen, J. (2005): Estimating biomass for boreal forests using ASTER satellite data combined with standwise forest inventory data. - Remote Sensing of Environment 99: 434-447.

[70] Neilson, E., Maclean, D., Arp, P., Meng, F.-R., Bourque, C. P., Bhatti, J. (2006): Modeling carbon sequestration with CO2Fix and a timber supply model for use in forest management planning. - Canadian Journal of Soil Science 86: 219-233.

[71] Nizami, S. M. (2012): The inventory of the carbon stocks in subtropical forests of Pakistan for reporting under Kyoto Protocol. - Journal of Forestry Research 23: 377384.

[72] Noble, I., Bolin, B., Ravindranath, N., Verardo, D., Dokken, D. (2000): Land Use, Land Use Change, and Forestry. - Cambridge University Press, Cambridge.

[73] Nugroho, N. (2006): Estimating carbon sequestration in tropical rainforest using integrated remote sensing and ecosystem productivity modelling: a case study in Labanan Concession Area, East Kalimantan, Indonesia. - Master Thesis, ITC, International Institute for Geo-information Science and Earth Observation, Enschede.

[74] PAEC-ASAD: Athar, G. R., Aijaz, A., Mumtaz, A. (2009): Greenhouse Gas Emission Inventory of Pakistan for the year 2007-08. - PAEC, Islamabad.

[75] Päivinen, R., Lehikoinen, M., Schuck, A., Häme, T., Väätäinen, S., Kennedy, P., Folving, S. (2001): Combining Earth Observation Data and Forest Statistics. - European Forest Institute, Joensuu.

[76] Pan, Y., Birdsey, R. A., Fang, J., Houghton, R., Kauppi, P. E., Kurz, W. A., Phillips, O. L., Shvidenko, A., Lewis, S. L., Canadell, J. G. (2011): A large and persistent carbon sink in the world's forests. - Science. DOI: 10.1126/science.1201609.

[77] Phua, M.-H., Ling, Z.-Y., Wong, W., Korom, A., Ahmad, B., Besar, N. A., Tsuyuki, S., Ioki, K., Hoshimoto, K., Hirata, Y. (2014): Estimation of above-ground biomass of a tropical forest in Northern Borneo using high-resolution satellite image. - Journal of Forest and Environmental Science 30: 233-242.

[78] Piao, S., Fang, J., Zhu, B., Tan, K. (2005): Forest biomass carbon stocks in China over the past 2 decades: estimation based on integrated inventory and satellite data. - Journal of Geophysical Research: Biogeosciences 110. https://doi.org/10.1029/2005JG000014. 
[79] Picard, N., Saint-André, L., Henry, M. (2012): Manual for Building Tree Volume and Biomass Allometric Equations: from Field Measurement to Prediction. - FAO, Rome.

[80] Plugge, D., Baldauf, T., Köhl, M. (2013): The global climate change mitigation strategy REDD: monitoring costs and uncertainties jeopardize economic benefits. - Climatic Change 119: 247-259.

[81] Pregitzer, K. S., Euskirchen, E. S. (2004): Carbon cycling and storage in world forests: biome patterns related to forest age. - Global Change Biology 10: 2052-2077.

[82] Ravindranath, N., Ostwald, M. (2008): Carbon Inventory Methods for National Greenhouse Gas Inventory, Carbon Mitigation and Roundwood Production Projects. Springer, Dordrecht, pp. 217-235.

[83] REDD+, L. (2006): Leaf Technical Guidance Series for the Development of a National or Subnational Forest Monitoring System for REDD+ (Module EF-D: Emission Factor for Deforestation). - Winrock International, Washington, DC.

[84] Rokityanskiy, D., Benítez, P. C., Kraxner, F., Mccallum, I., Obersteiner, M., Rametsteiner, E., Yamagata, Y. (2007): Geographically explicit global modeling of landuse change, carbon sequestration, and biomass supply. - Technological Forecasting and Social Change 74: 1057-1082.

[85] Rosenqvist, A., Shimada, M., Igarashi, T., Watanabe, M., Tadono, T., Yamamoto, H. (2003): Support to multi-national environmental conventions and terrestrial carbon cycle science by ALOS and ADEOS-II-the Kyoto \& Carbon Initiative. - IGARSS 2003 IEEE International Geoscience and Remote Sensing Symposium. Proceedings (IEEE Cat. No. 03CH37477) 2003, pp. 1471-1476.

[86] Rouse Jr, J. W., Haas, R., Schell, J., Deering, D. (1974): Monitoring Vegetation Systems in the Great Plains with ERTS. - NASA, Washington, DC.

[87] Sader, S. A., Joyce, A. T. (1988): Deforestation rates and trends in Costa Rica 1940 to 1983. - Biotropica 11-19.

[88] Schimel, D., Melillo, J., Tian, H., Mcguire, A. D., Kicklighter, D., Kittel, T., Rosenbloom, N., Running, S., Thornton, P., Ojima, D. (2000): Contribution of increasing $\mathrm{CO} 2$ and climate to carbon storage by ecosystems in the United States. - Science 287: 2004-2006.

[89] Sessa, R., Dolman, H. (2008): Terrestrial Essential Climate Variables for Climate Change Assessment, Mitigation and Adaptation (GTOS 52). - FAO, Rome.

[90] Shi, L., Liu, S. (2017): Methods of Estimating Forest Biomass: A Review. - In: Tumuluru, J. S. (ed.) Biomass Volume Estimation and Valorization for Energy. InTech, Rijeka.

[91] Silleos, N. G., Alexandridis, T. K., Gitas, I. Z., Perakis, K. (2006): Vegetation indices: advances made in biomass estimation and vegetation monitoring in the last 30 years. Geocarto International 21: 21-28.

[92] Sinha, S., Jeganathan, C., Sharma, L., Nathawat, M., Das, A. K., Mohan, S. (2016): Developing synergy regression models with space-borne ALOS PALSAR and Landsat TM sensors for retrieving tropical forest biomass. - Journal of Earth System Science 125: 725-735.

[93] Sitoe, A. A., Mandlate, L. J. C., Guedes, B. S. (2014): Biomass and carbon stocks of Sofala bay mangrove forests. - Forests 5: 1967-1981.

[94] Slonecker, T., Haack, B., Price, S. (2009): Spectroscopic analysis of arsenic uptake in Pteris ferns. - Remote Sensing 1: 644-675.

[95] Smithwick, E. A., Harmon, M. E., Remillard, S. M., Acker, S. A., Franklin, J. F. (2002): Potential upper bounds of carbon stores in forests of the Pacific Northwest. - Ecological Applications 12: 1303-1317.

[96] Stinson, G., Kurz, W., Smyth, C., Neilson, E., Dymond, C., Metsaranta, J., Boisvenue, C., Rampley, G., Li, Q., White, T. (2011): An inventory-based analysis of Canada's managed forest carbon dynamics, 1990 to 2008. - Global Change Biology 17: 2227-2244. 
[97] Thenkabail, P. S., Smith, R. B., De Pauw, E. 2000. Hyperspectral vegetation indices and their relationships with agricultural crop characteristics. - Remote Sensing of Environment 71: 158-182.

[98] Thomas, S. C., Martin, A. R. (2012): Carbon content of tree tissues: a synthesis. - Forests 3: 332-352.

[99] Tomppo, E., Olsson, H., Ståhl, G., Nilsson, M., Hagner, O., Katila, M. (2008): Combining national forest inventory field plots and remote sensing data for forest databases. - Remote Sensing of Environment 112: 1982-1999.

[100] Valentini, R., Matteucci, G., Dolman, A., Schulze, E.-D., Rebmann, C., Moors, E., Granier, A., Gross, P., Jensen, N., Pilegaard, K. (2000): Respiration as the main determinant of carbon balance in European forests. - Nature 404: 861.

[101] Wang, C., Feng, M.-C., Yang, W.-D., Ding, G.-W., Sun, H., Liang, Z.-Y., Xie, Y.-K., Qiao, X.-X. (2016): Impact of spectral saturation on leaf area index and aboveground biomass estimation of winter wheat. - Spectroscopy Letters 49: 241-248.

[102] Whittaker, R. H., Niering, W. A. (1975): Vegetation of the Santa Catalina Mountains, Arizona. V. Biomass, production, and diversity along the elevation gradient. - Ecology 56: 771-790.

[103] Winmore, G. T. (2012): Modelling spatial variations in wood volume and forest carbon stocks in dry forests of Southern Africa using remotely sensed data. - Msc. Thesis. University of Zimbabwe.

[104] Worldbank (2015): Readiness Preparation Proposal Assessment Note on a Proposed \{loan/credit\} in the Amount \{loan/credit $\}$ to the Islamic Republic of Pakistan. For REDD+ Readiness Preparation Support (p152465). - Worldbank, Washington, DC.

[105] Yingchun, L., Guirui, Y., Qiufeng, W., Yangjian, Z. (2012): Huge carbon sequestration potential in global forests. - Journal of Resources and Ecology 3: 193-201.

[106] Zhao, D., Huang, L., Li, J., Qi, J. (2007): A comparative analysis of broadband and narrowband derived vegetation indices in predicting LAI and CCD of a cotton canopy. ISPRS Journal of Photogrammetry and Remote Sensing 62: 25-33.

[107] Zhou, G., Wang, Y., Jiang, Y., Yang, Z. (2002): Estimating biomass and net primary production from forest inventory data: a case study of China's Larix forests. - Forest Ecology and Management 169: 149-157.

\section{APPENDIX A}

Table A1. List of allometric equations for major species

\begin{tabular}{c|c|c}
\hline Species & Model & Allometric equation \\
\hline General (coniferous) & $\mathrm{M}=\mathrm{a}\left(\mathrm{p}^{\times} \mathrm{D}^{2} \mathrm{H}\right)^{\mathrm{b}}$ & $\mathrm{AGB}=0.1645 \times\left(\mathrm{p}^{\times} \times \mathrm{D}^{2} \times \mathrm{H}\right)^{0.8586}$ \\
Pinus roxberghii (chir pine) & $\mathrm{M}=\mathrm{a}\left(\mathrm{D}^{2} \times \mathrm{H}\right)^{\mathrm{b}}$ & $\mathrm{AGB}=0.0224 \times\left(\mathrm{D}^{2} \times \mathrm{H}\right)^{0.9767}$ \\
Cedrus deodara (Deodar) & $\mathrm{M}=\mathrm{a}\left(\mathrm{D}^{2} \times \mathrm{H}\right)^{\mathrm{b}}$ & $\mathrm{AGB}=0.1779 \times\left(\mathrm{D}^{2} \times \mathrm{H}\right)^{0.8105}$ \\
Pinus Wallichiana (Kail) & $\mathrm{M}=\mathrm{a}\left(\mathrm{D}^{2} \times \mathrm{H}\right)^{\mathrm{b}}$ & $\mathrm{AGB}=0.0631 \times\left(\mathrm{D}^{2} \times \mathrm{H}\right)^{0.8798}$ \\
Pinus gerardiana (Chilghoza) & $\mathrm{M}=\mathrm{a} \times \mathrm{D}^{\mathrm{b}}$ & $\mathrm{AGB}=0.0253 \times \mathrm{D}^{2.6077}$ \\
Abies Pindrow (Fir) & $\mathrm{M}=\mathrm{a}\left(\mathrm{D}^{2} \times \mathrm{H}\right)^{\mathrm{b}}$ & $\mathrm{AGB}=0.0954 \times\left(\mathrm{D}^{2} \times \mathrm{H}\right)^{0.8114}$ \\
Picea smithiana (Spruce) & $\mathrm{M}=\mathrm{a}\left(\mathrm{D}^{2} \times \mathrm{H}\right)^{\mathrm{b}}$ & $\mathrm{AGB}=0.0843 \times\left(\mathrm{D}^{2} \times \mathrm{H}\right)^{0.8472}$ \\
Quercus ilex (Oak) & $\mathrm{M}=\mathrm{a}\left(\mathrm{D}^{2} \times \mathrm{H}\right)^{\mathrm{b}}$ & $\mathrm{AGB}=0.8277 \times\left(\mathrm{D}^{2} \times \mathrm{H}\right)^{0.6655}$ \\
\hline
\end{tabular}


Table A2. Description and formula of the categories of various vegetation indices

\begin{tabular}{|c|c|c|c|}
\hline Vegetation index & Formula & Sentinel-2 bands & Reference \\
\hline \multicolumn{4}{|c|}{ Broadband VIs } \\
\hline EVI - Enhanced VI & $\mathrm{EVI} 2=2.5 \times \frac{\mathrm{NIR}-\text { Red }}{\mathrm{NIR}+2.4 \mathrm{Red}+1}$ & $\begin{array}{l}\text { Whereas NIR is } \\
\text { spectral band } 8 \text {, } \\
\text { while the red is } \\
\text { spectral band } 4\end{array}$ & $\begin{array}{l}\text { Jiang et al., } \\
2008\end{array}$ \\
\hline $\begin{array}{c}\text { GNDVI - Green } \\
\text { Normalized Difference VI }\end{array}$ & GNDVI $=\frac{\text { NIR }- \text { Green }}{\text { NIR+Green }}$ & $\begin{array}{l}\text { Where NIR is } \\
\text { spectral band } 8 \\
\text { while Green is } \\
\text { spectral band } 3\end{array}$ & $\begin{array}{l}\text { Gitelson et al., } \\
1996\end{array}$ \\
\hline $\begin{array}{l}\text { NDVI - Normalized } \\
\text { Difference VI }\end{array}$ & NDVI $=\frac{\text { NIR }- \text { Red }}{\text { NIR }+ \text { Red }}$ & $\begin{array}{l}\text { Where NIR is } \\
\text { spectral band } 8 \text {, } \\
\text { while the red is } \\
\text { spectral band } 4\end{array}$ & $\begin{array}{c}\text { Rouse Jr et al., } \\
1974\end{array}$ \\
\hline SAVI - Soil Adjusted VI & SAVI $=\frac{\text { NIR -Red }}{\text { NIR }+ \text { Red }+\mathrm{L}} \times(1+\mathrm{L})$ & $\begin{array}{l}\text { Whereas NIR is } \\
\text { spectral band } 8 \text { and } \\
\text { Red is Spectral } \\
\text { band } 4\end{array}$ & Huete, 1988 \\
\hline $\begin{array}{l}\text { SQSR - Square Root } \\
\text { Simple Ratio }\end{array}$ & $\operatorname{SQSR}=\sqrt{\frac{\mathrm{NIR}}{\operatorname{Red}}}$ & $\begin{array}{c}\text { Whereas NIR is } \\
\text { spectral band } 8 \text { and } \\
\text { RED is spectral } \\
\text { band } 4\end{array}$ & Itkonen, 2012 \\
\hline $\begin{array}{c}\text { TSAVI - Transformed Soil } \\
\text { Adjusted VI }\end{array}$ & TSAVI $=\frac{a(N I R-a R-b)}{\left[a(N I R-b)+0.08\left(1+a^{2}\right)\right]}$ & $\begin{array}{c}\text { Where NIR spectral } \\
\text { band } 8 \text { and Red is } \\
\text { Spectral band } 4\end{array}$ & $\begin{array}{l}\text { Baret and } \\
\text { Guyot, } 1991\end{array}$ \\
\hline \multicolumn{4}{|c|}{ Canopy Water Content Indices } \\
\hline $\begin{array}{c}\text { NDII - Normalized } \\
\text { Difference Infrared Index }\end{array}$ & $\mathrm{NDII}=\frac{\mathrm{NIR}-\mathrm{SWIR}}{\mathrm{NIR}+\mathrm{SWIR}}$ & $\begin{array}{c}\text { Where: NIR is } \\
\text { spectral band } 8 \text {, } \\
\text { while the shortwave } \\
\text { infrared (SWIR) is } \\
\text { spectral band } 13\end{array}$ & Hunt et al., 2012 \\
\hline $\begin{array}{l}\text { NDWI - Normalized } \\
\text { Difference Water Index }\end{array}$ & $\mathrm{NDWI}=\frac{\mathrm{NIR}-\mathrm{SWIR}}{\mathrm{NIR}+\mathrm{SWIR}}$ & $\begin{array}{l}\text { Where: NIR is } \\
\text { spectral band } 8 \text {, } \\
\text { while shortwave } \\
\text { infrared (SWIR) is } \\
\text { spectral band } 12\end{array}$ & Gao, 1996 \\
\hline \multicolumn{4}{|c|}{ Narrow Red Edge Band VIs } \\
\hline $\begin{array}{l}\text { RE-EVI - Re-Edge } \\
\text { Enhanced VI }\end{array}$ & $\mathrm{RE}_{\mathrm{RVI}}=2.5 \times \frac{\mathrm{NIR}-\mathrm{RE}}{\mathrm{NIR}+2.4 \mathrm{RE}+1}$ & $\begin{array}{l}\text { Where: NIR is } \\
\text { spectral band } 8 \text {, } \\
\text { While the red-edge } \\
\text { is spectral band } 6\end{array}$ & $\begin{array}{l}\text { Abdel-Rahman } \\
\text { et al., } 2017\end{array}$ \\
\hline $\begin{array}{c}\text { RENDVI - Red-Edge } \\
\text { Normalized Difference VI }\end{array}$ & RENDVI $=\frac{\text { NIR }- \text { red }}{\text { NIR }+ \text { red }}$ & $\begin{array}{l}\text { Where: NIR is } \\
\text { spectral band } 8 \text {, } \\
\text { while the red-edge } \\
\text { spectral band } 6\end{array}$ & $\begin{array}{l}\text { Chen et al., } \\
2007 \mathrm{a}\end{array}$ \\
\hline $\begin{array}{l}\text { RERVI - Red Edge Ratio } \\
\text { Vegetation Index }\end{array}$ & RERVI $=\frac{\mathrm{NIR}}{\mathrm{RE}}$ & $\begin{array}{c}\text { Where: NIR is } \\
\text { spectral band } 8 \text {, } \\
\text { while the red-edge } \\
\text { is spectral band } 6\end{array}$ & Cao et al., 2016 \\
\hline
\end{tabular}


Table A3. Biomass, carbon stock and $\mathrm{CO}_{2}$ e estimated per plot in study area

\begin{tabular}{|c|c|c|c|c|c|c|c|c|c|c|c|c|}
\hline $\begin{array}{l}\text { Plot } \\
\text { No. }\end{array}$ & Aspect & $\begin{array}{c}\text { Elevation } \\
(\mathbf{m})\end{array}$ & Slope & Forest type & $\begin{array}{l}\text { Crown } \\
\text { cover }\end{array}$ & $\begin{array}{l}\text { AGB } \\
\text { (t/ha) }\end{array}$ & $\begin{array}{l}\text { BGB } \\
\text { (t/ha) }\end{array}$ & $\begin{array}{c}\begin{array}{c}\text { Total B } \\
\text { (t/ha) }\end{array} \\
\end{array}$ & $\begin{array}{l}\text { AGC } \\
\text { (t/ha) }\end{array}$ & $\begin{array}{l}\text { BGC } \\
\text { (t/ha) }\end{array}$ & $\begin{array}{c}\text { Total C } \\
\text { (t/ha) }\end{array}$ & $\mathrm{CO}_{2} \mathrm{e}$ \\
\hline 1 & Northern & 1942 & 55 & Moist Temperate & 80 & 203.83 & 52.99 & 256.83 & 95.80 & 24.90 & 120.71 & 441.79 \\
\hline 2 & Northern & 1927 & 55 & Moist Temperate & 70 & 116.40 & 30.26 & 146.67 & 54.71 & 14.22 & & 252.29 \\
\hline 3 & Eastern & 1884 & 90 & Moist Temperate & 100 & 171.53 & 44.59 & 216.13 & 80.62 & 20.96 & 101.58 & 371.79 \\
\hline 4 & Northern & 1913 & 31 & Moist Temperate & 80 & 112.99 & 29.38 & 142.38 & 53.11 & 13.81 & 66.92 & 244.92 \\
\hline 5 & Eastern & 1798 & 60 & Moist Temperate & 70 & 149.75 & 38.94 & 188.69 & 70.39 & 18.30 & 88.69 & 324.59 \\
\hline 6 & Eastern & 1759 & 0 & Moist Temperate & 100 & 198.11 & 51.51 & 249.62 & 93.11 & & 117.33 & 429.40 \\
\hline 7 & Northern & 1753 & 70 & Moist Temperate & 65 & & & & & & & 229.63 \\
\hline 8 & Eastern & 1786 & 60 & Moist Temperate & 70 & 193.58 & 50.33 & 243.92 & 90.98 & 23.66 & 114.64 & 419.58 \\
\hline 9 & Northern & 1823 & 55 & Moist Temperate & 40 & 125.27 & 32.57 & 157.84 & 58.88 & 15.31 & 74.19 & 271.52 \\
\hline 10 & Northern & 1305 & 45 & Moist Temperate & 60 & 194.13 & 50.47 & 244.60 & 91.24 & 23.72 & 114.96 & 420.76 \\
\hline 11 & Northern & 1361 & 58 & Moist Temperate & 55 & & & & & & & \\
\hline 12 & Northern & 1325 & 50 & Moist Temperate & 65 & & & 182.69 & & & 85.86 & 314.26 \\
\hline 13 & Northern & 1420 & 68 & Moist Temperate & 95 & 170.91 & 44.44 & 215.35 & 80.33 & 20.89 & 101.22 & 370.45 \\
\hline 14 & Western & 1403 & 60 & Moist Temperate & 95 & 110.40 & 28.70 & 139.11 & 51.89 & 13.49 & 65.38 & 239.29 \\
\hline 15 & Southern & 1431 & 50 & Moist Temperate & 5 & 115.76 & 30.09 & 145.86 & 54.41 & 14.15 & 68.55 & 250.90 \\
\hline 16 & Northern & 1416 & 75 & Moist Temperate & 50 & & & & & & & \\
\hline 17 & Northern & 1441 & 65 & Moist Temperate & 95 & & & & & 15.21 & 73.72 & 269.81 \\
\hline 18 & Eastern & 1470 & 53 & Moist Temperate & 90 & 113.31 & 29.46 & 142.77 & 53.26 & 13.85 & 67.10 & 245.59 \\
\hline 19 & Northern & 1468 & 0 & Moist Temperate & 50 & 108.45 & 28.19 & 136.66 & 50.97 & 13.25 & 64.23 & 235.07 \\
\hline 20 & Western & 1820 & 52 & Moist Temperate & 75 & 135.36 & 35.19 & 170.56 & 63.62 & 16.54 & 80.16 & 293.40 \\
\hline 21 & Northern & 1605 & 75 & Moist Temperate & 80 & & & & & & & \\
\hline 22 & Northern & & 73 & Ioist Temperate & 90 & & & & & & 102.61 & 375.55 \\
\hline 23 & Northern & 1667 & 80 & Moist Temperate & 80 & 151.05 & 39.27 & 190.32 & 70.99 & 18.46 & 89.45 & 327.39 \\
\hline 24 & Western & 1680 & 50 & Moist Temperate & 90 & 146.90 & 38.19 & 185.09 & 69.04 & 17.95 & 86.99 & 318.40 \\
\hline 25 & Northern & 1419 & 87 & Moist Temperate & 50 & 119. & 31. & 151.02 & 56.33 & .65 & 70.98 & 259.79 \\
\hline 26 & & 1388 & 88 & oist Temperate & 45 & & & & & & 68.01 & 48.92 \\
\hline 27 & Northern & & 73 & Ioist Temperate & 15 & & & & & & & 256.90 \\
\hline 28 & Northern & 1500 & 67 & Moist Temperate & 40 & 151.36 & 39.35 & 190.71 & 71.14 & 18.49 & 89.64 & 328.06 \\
\hline 29 & Western & 1930 & 90 & Moist Temperate & 85 & 134.91 & 35.08 & 169.99 & 63.41 & 16.49 & 79.89 & 292.41 \\
\hline 30 & Western & 2132 & 95 & Moist Temperate & 90 & 170.06 & 44.21 & 214.27 & 79.93 & 20.78 & 100.71 & 368.59 \\
\hline 31 & Southern & & 110 & & 80 & & & & & & & 383.65 \\
\hline 32 & Northern & & 60 & Moist $\mathrm{Te}$ & 80 & & & & & & & 375.75 \\
\hline 33 & Northern & 1711 & 50 & Moist Temperate & 95 & 153.59 & 39.94 & 193.53 & 72.19 & 18.77 & 90.96 & 332.92 \\
\hline 34 & Western & 1548 & 70 & Chir Pine Forest & 20 & 132.67 & 34.49 & 167.17 & 62.36 & 16.21 & 78.57 & 287.57 \\
\hline 35 & Northern & 1150 & 60 & Chir Pine Forest & 75 & 174.88 & 45.46 & 220.35 & 82.19 & 21.37 & 103.57 & 379.05 \\
\hline 36 & Southern & & 70 & hir Pine Forest & 80 & & & & & & & 355.97 \\
\hline 37 & Northern & 1522 & 75 & Chir Pine Forest & 80 & 279.59 & 72.69 & 352.29 & 131.41 & 34.17 & 165.58 & 606.01 \\
\hline 38 & Northern & 1008 & 75 & Chir Pine Forest & 60 & 86.19 & 22.41 & 108.60 & 40.51 & 10.53 & 51.04 & 186.82 \\
\hline 39 & Western & 1543 & 55 & Chir Pine Forest & 65 & 118.10 & 30.70 & 148.81 & 55.51 & 14.43 & 69.94 & 255.98 \\
\hline 40 & Southern & 1525 & 75 & Chir Pine Forest & 65 & 179.58 & 46.69 & 226.28 & 84.41 & 21.95 & 106.35 & 389.25 \\
\hline 41 & Southern & & 50 & Chir Pine Forest & 25 & & & & 66.35 & 17.25 & 83.59 & 305.98 \\
\hline 42 & Southern & 1353 & 60 & Chir Pine Forest & 10 & 145.65 & 37.87 & 183.52 & 68.46 & 17.79 & 86.25 & 315.69 \\
\hline 43 & Eastern & 1017 & 25 & Chir Pine Forest & 30 & 136.51 & 35.49 & 172.01 & 64.16 & 16.68 & 80.84 & 295.89 \\
\hline 44 & Western & 1300 & 45 & Chir Pine Forest & 35 & 111.33 & 28.95 & 140.28 & 52.33 & 13.60 & 65.93 & 241.31 \\
\hline 45 & Northern & 1043 & 75 & Chir Pine Forest & 65 & 161.75 & 42.06 & 203.80 & 76.02 & 19.77 & 95.79 & 350.59 \\
\hline 46 & Northern & 1029 & 60 & Chir Pine Forest & 60 & & & & 63.96 & & 80.59 & 294.97 \\
\hline 47 & Eastern & 998 & 40 & Chir Pine Forest & 20 & 105.31 & 27.38 & 132.69 & 49.49 & 12.87 & 62.37 & 228.26 \\
\hline 48 & Southern & 2319 & 72 & Chir Pine Forest & 90 & 115.00 & 29.90 & 144.91 & 54.05 & 14.05 & 68.12 & 249.27 \\
\hline 49 & Southern & 2365 & 80 & Moist Temperate & 70 & 256.76 & 66.76 & 323.51 & 120.68 & 31.37 & 152.05 & 556.51 \\
\hline 50 & & & 90 & & 100 & & & & & & & 476.86 \\
\hline 51 & Northern & & 73 & Moist Temperate & 70 & & 35.66 & 172.81 & 64.46 & 16.76 & 81.22 & 297.26 \\
\hline 52 & Northern & 1612 & 0 & Moist Temperate & 60 & 161.82 & 42.07 & 203.89 & 76.06 & 19.77 & 95.83 & 350.74 \\
\hline 53 & Northern & 1662 & 70 & Moist Temperate & 55 & 105.23 & 27.36 & 132.59 & 49.46 & 12.86 & 62.32 & 228.08 \\
\hline 54 & & 1681 & 0 & Moist Temperate & 55 & 196.88 & 51.19 & 248.07 & 92.53 & 24.06 & 116.59 & 426.72 \\
\hline 55 & Eastern & 1121 & 40 & Moist Temperate & 70 & 138.57 & 36.03 & 174.61 & 65.13 & 16.93 & 82.06 & 300.36 \\
\hline
\end{tabular}

$\mathrm{AGB}=$ Above Ground Biomass, $\mathrm{BGB}=$ Below Ground Biomass, AGC $=$ Above Ground Carbon, $\mathrm{BGC}=$ Below Ground Carbon and $\mathrm{CO}_{2} \mathrm{e}=$ carbon di oxide equivalent 


$$
-814-
$$

\section{APPENDIX B}

Relationship between above ground biomass (AGB), several vegetation indices was assessed using regression analysis which can be seen below.

Figure B1. Scatter plot ( $a, b, c, d, e, f)$ derived using SigmaPlot 14.0 showing the relationship, regression equation and $R$-square value between broadband vegetation indices and above ground biomass
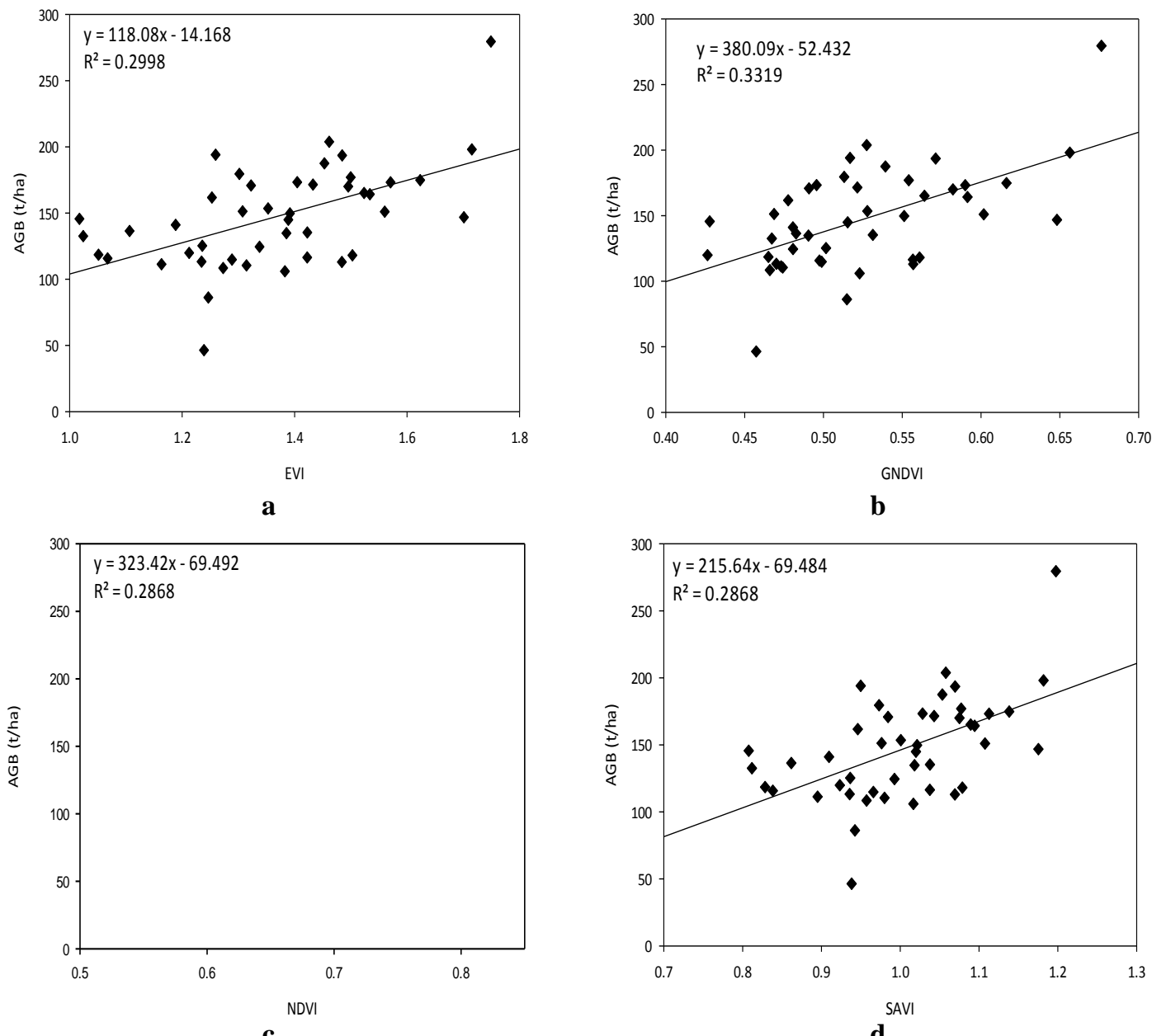

b

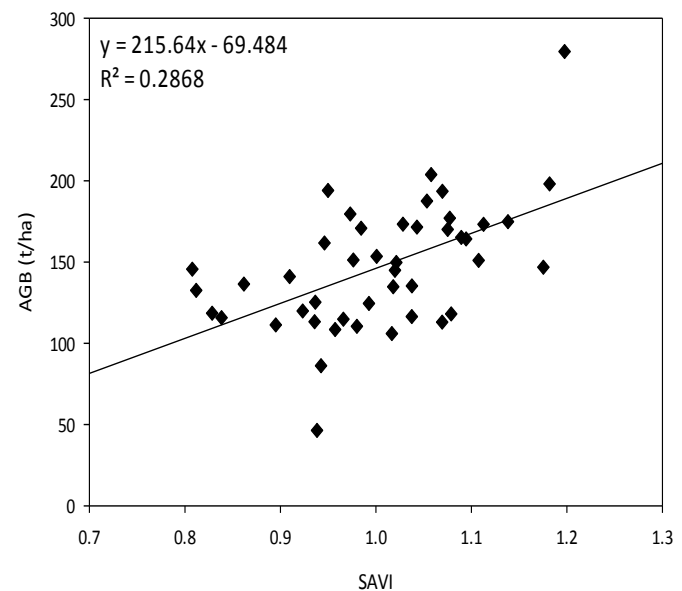

d
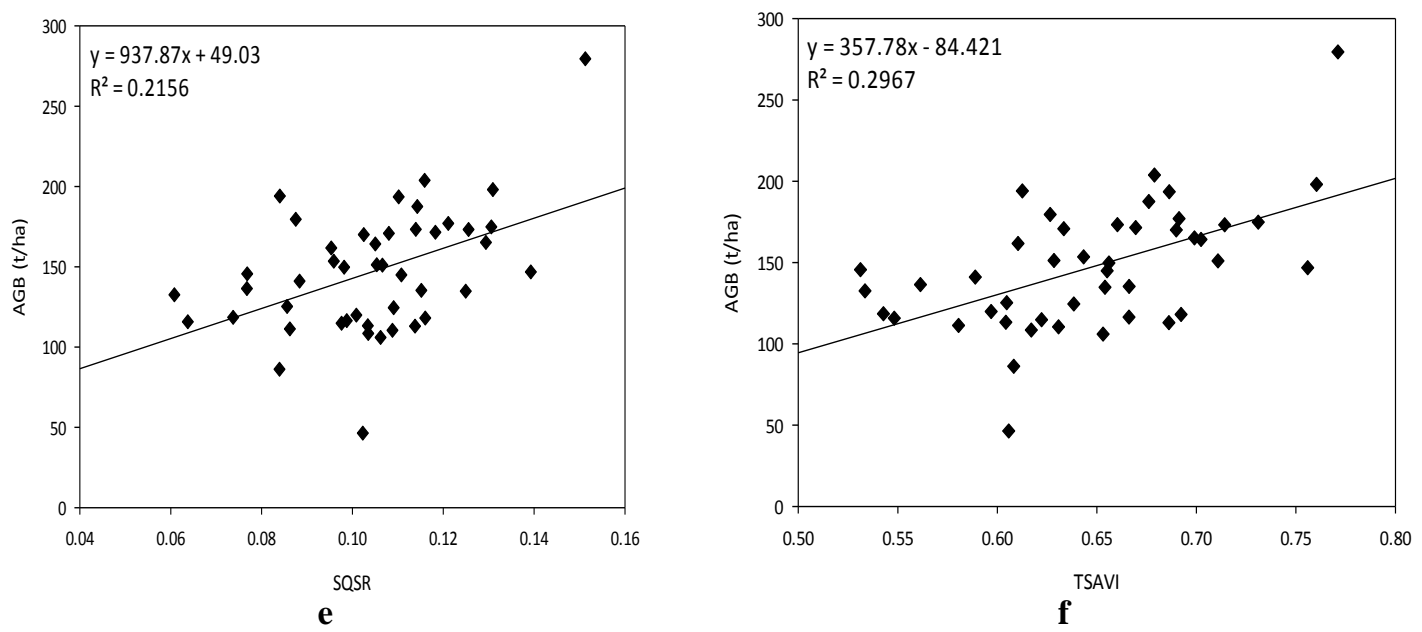


$$
-815-
$$

Figure B2. Scatter plot a and b derived using SigmaPlot 14.0 showing regression equation, $R$ square value and relationship between canopy water vegetation indices and above ground biomass

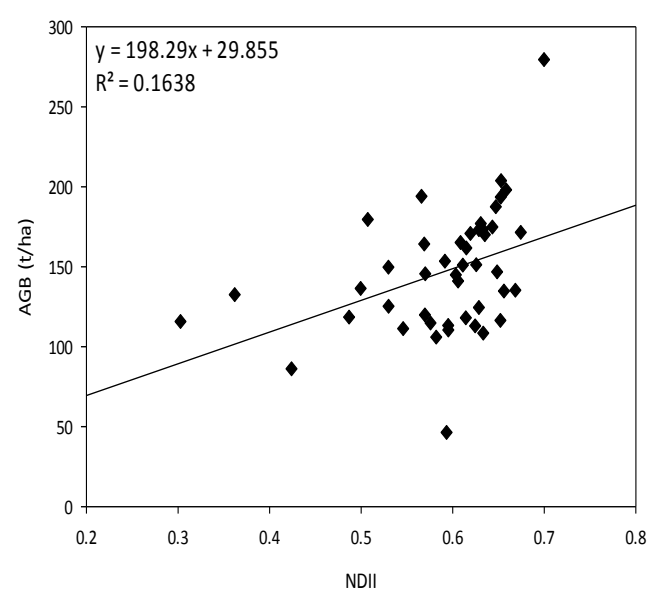

$\mathbf{a}$

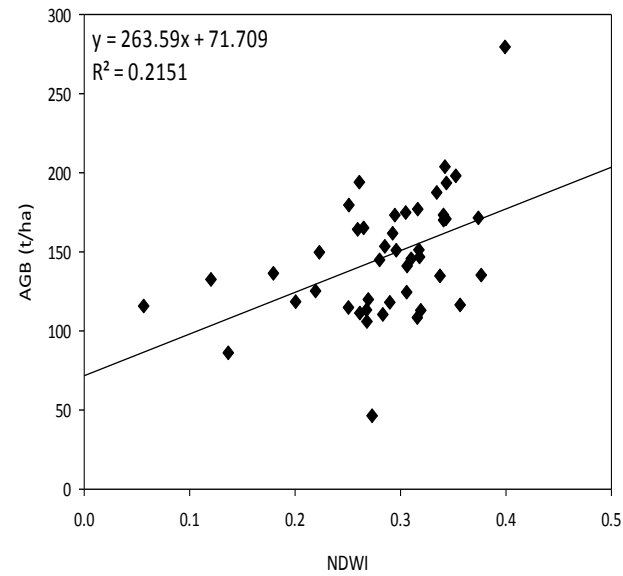

b

Figure B3. Scatter plot ( $a, b, c)$ derived using SigmaPlot 14.0 showing the relationship, regression equation and $R$-square value between narrow red-edge band vegetation indices and above ground biomass

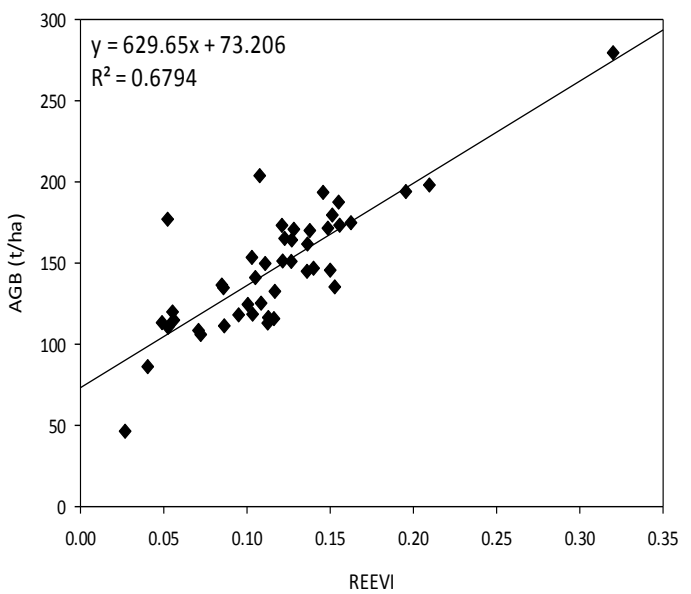

$\mathbf{a}$

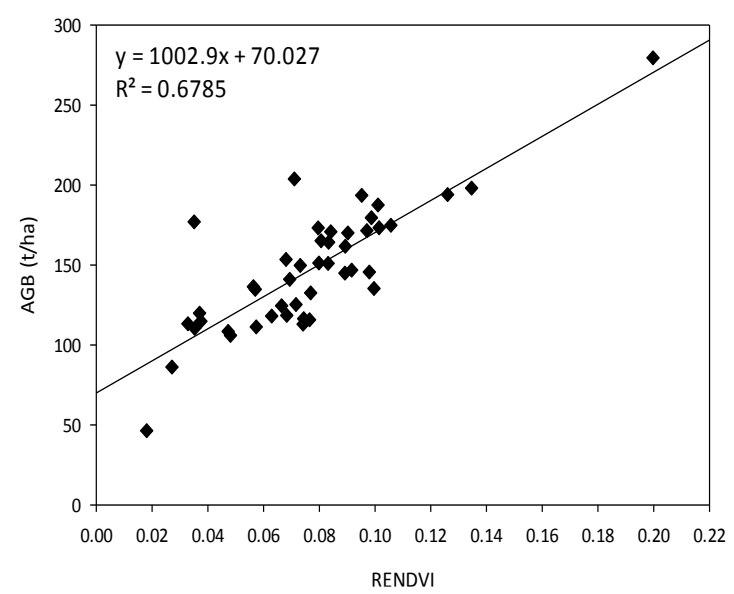

b

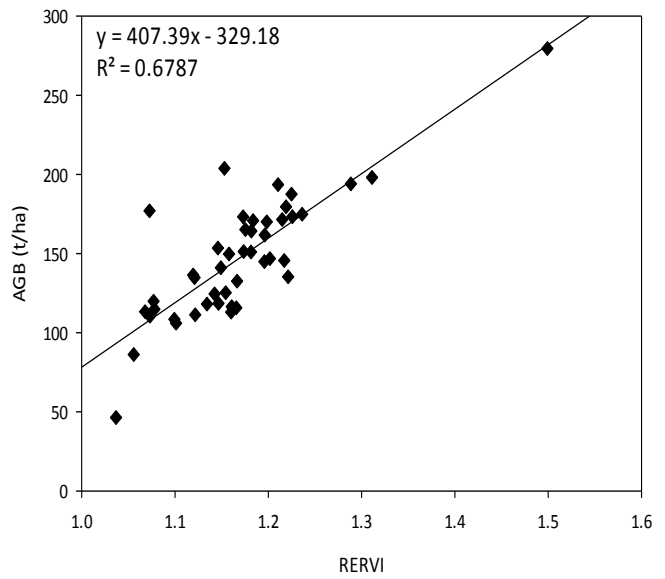

c 